\title{
The Impact of Financial Architecture on Technical Innovation
}

\author{
Luca Giordano $^{1,2}$ \& Claudia Guagliano ${ }^{3}$ \\ ${ }^{1}$ International Organization of Securities Commission (IOSCO), Madrid, Spain. \\ ${ }^{2}$ Commissione Nazionale per le Società e la Borsa (CONSOB), Rome, Italy. \\ ${ }^{3}$ European Securities and Markets Authority (ESMA), Paris, France. \\ Correspondence: Luca Giordano, CONSOB, via G.B. Martini 3, 00198, Roma, Italy.
}

Received: April 20, 2016

Accepted: May 10, 2016

Available online: May 27, 2016

doi:10.11114/aef.v3i3.1642

URL: http://dx.doi.org/10.11114/aef.v3i3.1642

\begin{abstract}
While a large body of literature argues that financial intermediaries exert a causal impact on long-run growth, it doesn't investigate the links between financial architecture and technological change. We seek to shed light on these links by exploring the relationship between financial architecture (FA) and what is assumed to be one of the main drivers of economic growth, the technological change (TC). We apply the stochastic frontier analysis (SFA) to estimate and decompose total factor productivity growth (TFP) into its main components: efficiency change (EC) and technological change (TC). As a second step we regress the technological change (TC) on a set of variables capturing the financial characteristics ("financial architecture") of a sample of OECD countries in order to identify which features of the financial system affect the country's rate of technological change. Our results confirm that better functioning financial systems - open and competitive - improve resource allocation and accelerate the country's rate of technological change with positive impact on long-run economic growth.
\end{abstract}

Keywords: financial structure, economic growth, technological change, stochastic frontier analysis (SFA), total factor productivity (TFP)

\section{Introduction}

A long-standing debate in the economic literature focused on the relation between market-bank orientation and economic growth (Allen and Gale, 2000), without, however, establishing no clear-cut prediction regarding the superiority of bank-based or market-based finance in promoting the efficient allocation of funding (Levine, 2002).

In this paper we slightly shift the focus of research by providing new empirical evidence on the relationship between the features of a country's financial system - what we define financial architecture (FA) - and the rate of technological change (TC) ${ }^{1}$. We go beyond the traditional division between bank-based and market-based financial systems and assume that what really matters is the broader concept of FA, which includes market-bank orientation (MB) and a wide set of other relevant features of financial systems (FS, financial structure). At the same time, instead of studying the relationship between financial features and economic growth, we investigate the relation between FA and one of the most important source of growth, $\mathrm{TC}^{2}$.

Financial structure can affect economic outcome in two ways. First, the pro-cyclicality of credit supply is likely to lead to an inefficient allocation of external funding. In good times, banks finance a large quantity of bad project, harming economy-wide productivity growth (Rajan and Ramcharan, 2015). Second, banks engage in excessive forbearance of non-performing loans, tending to refinance low-productivity projects while refusing funds to new, more productive projects (Peek and Rosengren, 2005; Caballero, Hoshi and Kashyap, 2008). By engaging in excessive forbearance, banks distort the process of market entry and exit, and in doing so harm aggregate productivity growth (Disney, Haskel and Heden, 2003). By contrast, markets prevent this misallocation: owing to higher coordination costs, market agents can credibly commit to refuse refinance unprofitable projects (Dewatripont and Maskin, 1995; Langfield and Pagano, 2015).

\footnotetext{
The views expressed are those of the authors and do not necessarily reflect the opinions of CONSOB, IOSCO and ESMA.

1 Technological change (TC) is also referred to as "technical change" or "technological innovation".

2 Historically, technological innovations have tended to occur in countries with market-based financial structure (Allen, 1993).
} 
FA is captured by the combination of two sets of variables defined as MB and FS. We follow Tadesse $(2002,2007)$ to construct MB, i.e. the degree of market-based orientation of a financial system, as principal component of three indices measuring the relative size, activity and efficiency of the financial market in a given country with respect to the banking sector (see section 3.1 for more details). FS includes information related to foreign presence and competition level in the banking system and other stock market structural characteristics.

We follow the literature on technological efficiency and productivity, focusing on Stochastic Frontier Analysis (SFA) models to obtain Technological Change (TC). SFA models are able to disentangle the main sources of Total Factor Productivity (TFP): TC and Efficiency Change (EC). TC is assumed to push the frontier of potential production upward, while EC reflects the capability of productive units to improve actual production with a set of given inputs and available technology (in other words the ability to reach a given frontier). In this paper we focus on TC as a primary source of economic growth. There is a lot of empirical evidence showing clearly that economies characterized by higher level of technological change have generally more competitive and globalized companies and, as a result, higher GDP growth rates and lower unemployment levels. This is particularly important for mature economies of advanced countries challenged by the competition from emerging markets.

Our empirical analysis is based on a dataset including 27 OECD countries during the 1996-2010 period. We limit our work to studying OECD countries because the stochastic frontier model assumes a common production technology frontier for all countries in the sample, and pooling developed and non-developed countries together would be conceptually erroneous. We also include a set of time trend variables in our estimation, acknowledging the presence of common shocks that could affect the rate of technological change due to the different phases of economic cycle (shock versus tranquil period).

Research that clarifies our understanding of the role of finance as a driver of economic growth (via technological change) has strong policy implications. Information about the impact of finance on economic growth will influence the priority that policy makers and advisors attach to reforming financial sector policies. Furthermore, convincing evidence that the financial system influences long-run economic growth will advertise the urgent need for research on the political, legal and regulatory determinants of financial development and on those features of financial system which better contribute to the achievement of a desired economic outcome.

Our results show that more competitive, inclusive and open financial markets promote innovation and technological change. From a policy point of view, this is particularly relevant given the recent so called Capital Markets Union (CMU) proposal at the EU level.

The paper is organized as follows. Section 2 describes the related literature and develops our hypotheses. In Section 3 we explain the methodology while in Section 4 we show our dataset. The empirical results are described in Section 5 and Section 6 concludes.

\section{Literature review}

In this section we review the literature investigating if different features of financial systems $(F A=M B+F S)$ affect countries' macroeconomic performance (which encompasses not only the GDP growth but also others aspects such as the volatility of growth, the innovation and competitiveness of economic systems, the country's technological change, etc.).

In considering the importance of financial structure for economic growth economists generally focused on whether bank-based or market-based financial systems are more conducive to growth with inconclusive results. Beck et al (2000) test four theoretical alternative views on financial structure: 1) the bank-based view highlights the positive role of banks in mobilizing resources, identifying good projects, monitoring managers and managing risks and highlights the comparative shortcomings of market-based systems; 2) the market-based view highlights the positive role of markets in promoting economic success, facilitating diversification and the customization of risk management devices; 3) the law and finance view argues that the legal system is the primary determinant of the effectiveness of the financial system in facilitating innovation and growth and rejects the entire bank-based versus market-based debate; 4) finally, the financial services view stresses that financial systems provide key financial services that are crucial for firm creation, industrial expansion and economic growth, while the division between banks and markets in providing these services is of secondary importance. Using three different methodologies (cross-country, industry and firm-level approach), they find that financial structure does not help in understanding economic growth, industrial performance or firm expansion. Therefore, their results are inconsistent with both the market-based and bank-based views, while they are consistent with both the financial services and the law and finance views. We find the same results in Levine (2002): after controlling for the overall level of financial development, information on financial structure (always limited to whether the system is bank-based or market-based) does not help in explaining cross-country differences in financial development. 
Tadesse (2002 and 2007), however, using a cross-country approach, argues that while market-based systems outperform bank-based systems among countries with developed financial sectors, bank-based systems are far better among countries with underdeveloped financial sectors.

Carlin and Mayer (2003) examine the relation between the institutional structures of advanced OECD countries and the comparative growth and investment of 27 industries in those countries over the period 1970-1995. They find a strong relation between the structure of countries' financial systems, the characteristics of industries, and the growth and investment of industries in different countries.

Some recent papers have tried to widen the concept of financial structure, going beyond the traditional division between bank-based and market-based systems. Gole and Sun (2013) enlarge the definition of financial structure using data for four concepts: competition, financial buffers, financial globalization and non-traditional bank intermediation. They use some measurements of financial structure and relate them to four indicators of economic outcomes: the growth of real GDP per capita, the volatility of real growth, financial stability and income inequality. They find that some financial intermediary structures are likely to be more closely related to positive economic outcomes than others. For instance, protective financial buffers within institutions have been associated with better economic performance, and a domestic financial system that is dominated by some types of non-traditional bank intermediation or that has a high proportion of foreign banks has in some cases been associated with adverse economic outcomes, especially during the financial crisis. Their results also suggest that there may be some trade-offs between beneficial effects on growth and stability of some financial structures. For example, the positive association of financial buffers with growth can diminish above a certain, relatively high, threshold, i.e. a too-safe system may limit the available funds for credit and hence growth.

\section{Testing the impact of financial architecture on technological change}

We estimate a model which captures the effect of several features of a country's financial system on the rate of technological change. First, we obtain the technological change for a sample of countries in different years by decomposing the Total Factor Productivity (we apply the Stochastic Frontier Analysis estimation) and then we study how this variable (TC) is affected by several features of countries' financial system (FA $=\mathrm{MB}+\mathrm{FS})$.
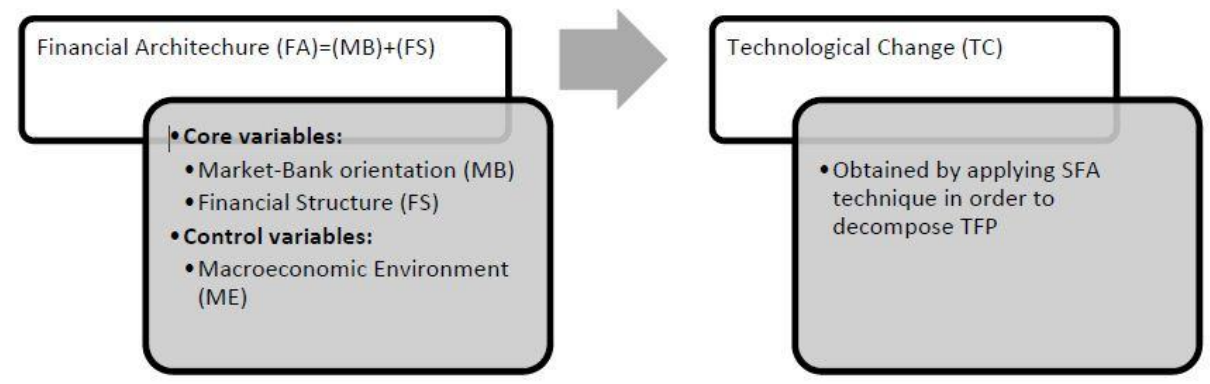

More specifically, we regress TC on FA and different sets of independent variables, seizing various characteristics of the macroeconomic environment of the countries included in our sample (ME). Our model is the following:

$$
T C_{i t}=\alpha_{i t}+\beta_{1} M B_{i t}+\beta_{2} F S_{i t}+\beta_{3} M E_{i t}+\varepsilon_{i t}
$$

The dependent variable in the regression, technological change (TC), is calculated on the basis of the stochastic frontier analysis (SFA) methodology described in paragraph 3.1. Market-Bank orientation (MB) is a continuous variable representing the degree of stock market orientation of a financial system constructed following the approach of Tadesse (2007; see paragraph 3.2).

Financial Structure (FS) variable includes the following factors:

- $\quad$ foreign banks among total banks: the percentage of the number of foreign owned banks over the number of the total banks in an economy (expected sign: positive) ${ }^{3}$.

- bank concentration: the assets of three largest commercial banks as a share of total commercial banking assets 4 (expected sign: uncertain).

\footnotetext{
${ }^{3}$ A foreign bank is a bank where 50 percent or more of its shares are owned by foreigners (Claessens and van Horen, 2012).

${ }^{4}$ Total assets include total earning assets, cash and due from banks, foreclosed real estate, fixed assets, goodwill, other intangibles, current tax assets, deferred tax assets, discontinued operations and other assets. The expected sign of this variable is uncertain since the higher bank concentration could be a result of higher bank efficiency hypothesis or simply stemming from an oligopolistic market structure. In the first case more efficient banks are able to gain larger market share and as a result the concentration will rise. In the second case the bank concentration is merely a result of a non-competitive market structure and hence bank can exert higher market power at borrowers detrimental (see Stigler, 1964; Demsetz, 1973; Berger, 1995).
} 
- $\quad$ bank lending-deposit spread: the difference between lending rate and deposit rate ${ }^{5}$ (expected sign: negative).

- $\quad$ stock price volatility: the average of the 360-day volatility of the national stock market index (expected sign: uncertain).

- number of listed companies: number of domestically incorporated companies listed on the country's stock exchanges at the end of the year per 1,000,000 people $^{6}$ (expected sign: positive).

bank capitalization: ratio of bank capital and reserves to total assets. Capital and reserves include funds contributed by owners, retained earnings, general and special reserves, provisions, and valuation adjustments. Total assets include all non-financial and financial assets $^{7}$ (expected sign: uncertain).

Macroeconomic Environment (ME) contains the following set of variables:

- $\quad$ lagged real GDP per capita growth ${ }^{8}$ (expected sign: positive).

- $\quad$ lagged output gap in percent of potential GDP: output gaps for advanced economies are calculated as actual GDP less potential GDP as a percent of potential GDP ${ }^{9}$ (expected sign: positive).

- $\quad$ general government total expenditure: it consists of total expense and the net acquisition of nonfinancial assets (expected sign: uncertain).

trade openness growth: it is the annual variation of trade openness, calculated as total trade, i.e. the sum of exports and imports of goods and services, relative to GDP. We use the annual variation instead of the annual level since it could better proxy the dynamics of countries' trade integration which is a long term phenomenon with several grades of stickiness (expected sign: positive).

Descriptive statistics for the control variables are presented in the Appendix.

\subsection{Financial Architecture}

There is no uniformly accepted empirical definition of the market-bank orientation of a given country. We follow the approach of Tadesse (2007) and construct a continuous variable, MB, as an index of the degree of stock market orientation of a financial system. In particular, MB is based on three indices that measure the relative (i) size, (ii) activity and (iii) efficiency of the stock market in a given country with respect to those of the banking sector. Therefore the variable MB reflects the principal component of these three variables (PCA $)^{10}:$ market size, market activity and market efficiency. By construction, higher values of MB indicate a more market-oriented financial system.

Market size measures the relative size of stock markets to that of banks in the financial system. The size of the domestic stock markets is measured by the market capitalization of domestic stocks relative to the GDP of the country ${ }^{11}$.The size of the banking sector is measured by the bank credit ratio defined as the claims of the banking sector against the private real sector as a percentage of $\mathrm{GDP}^{12}$. Therefore, market size is the ratio between market capitalization and the claims of the banking sector. Larger values indicate more market orientation in terms of relative size.

Market activity measures the activity of stock markets relative to that of banks. It is denoted by the ratio of total value of stocks traded to bank credit ratio. Total value traded as a share of GDP measures stock market activity relative to economic activity; bank credit ratio (defined above) indicates the importance of banks in the economic activities of the

\footnotetext{
${ }^{5}$ Lending rate is the rate charged by banks on loans to the private sector and deposit interest rate is the rate offered by commercial banks on three-month deposits. Higher bank lending-deposit spread is associated with higher banks market power which is in turn a result of a lack of competitiveness.

${ }^{6}$ It does not include investment companies, mutual funds, or other collective investment vehicles. Since equity capital only has a residual claim on corporate earnings, it can be used to finance projects with uncertain and long-term returns, such as research, product development, innovation or the opening of new markets. These characteristics make equity unique and the only standardised financial instrument dedicated to finance genuine innovation and value creation, which is associated with uncertainty and the very basis for economic progress (Knight, 1921).

${ }_{7}^{7}$ Capital includes Tier 1 capital (paid-up shares and common stock), which is a common feature in all countries' banking systems, and total regulatory capital, which includes several specified types of subordinated debt instruments that need not be repaid if the funds are required to maintain minimum capital levels (these comprise Tier 2 and Tier 3 capital). Due to differences in national accounting, taxation, and supervisory regimes, these data are not strictly comparable across countries.

${ }^{8}$ GDP per capita is gross domestic product divided by midyear population. GDP is the sum of gross value added by all resident producers in the economy plus any product taxes and minus any subsidies not included in the value of the products. It is calculated without making deductions for depreciation of fabricated assets or for depletion and degradation of natural resources. Data are in constant 2005 U.S. dollars.

${ }_{9}$ Estimates of output gaps are subject to a significant margin of uncertainty. For a discussion of approaches to calculating potential output, see De Masi (1997).

${ }^{10}$ We apply standard principal component analysis and retain only the first component.

${ }^{11}$ Stock market capitalization is defined as the total value of all listed shares in a stock market as a percentage of GDP

${ }^{12}$ It includes the financial resources provided to the private sector by domestic money banks as a share of GDP. Domestic money banks comprise commercial banks and other financial institutions that accept transferable deposits, such as demand deposits. This excludes claims of non-bank intermediaries, and credits to the public sector. Market size therefore combines the two size measures as a ratio of the capitalization ratio to bank credit ratio.
} 
private sector.

Market efficiency measures the relative efficiency of a country's stock markets with respect to that of its banks. Efficiency of stock markets is measured by the stock market turnover ratio, which is defined to be the total value of shares traded during the period divided by the average market capitalization for the period. High turnover is used as an indicator of low transaction costs ${ }^{13}$. Efficiency of banking is measured by bank overhead ratio, defined to be the ratio of banking overhead costs to banking assets. Market efficiency thus is the product of stock market turnover ratio and bank overhead ratio ${ }^{14}$.

We take the principal component of the three series (market size, market activity and market efficiency) and compute the composite measure $M B$.

\subsection{Estimating and decomposing TFP: Stochastic Frontier Analysis}

Productivity growth, in general, is composed by technological change (TC) and EC (efficiency change): SFA allows us to distinguish between the two. This can be further understood by viewing output growth from the perspective of a frontier of production possibilities where countries can be operating either on or within the frontier, with the distance from the frontier reflecting inefficiency. Over time, a country's frontier can shift, indicating TC, or a country can move towards or away from the frontier which represents $\mathrm{EC}^{15}$ (Koop et al., 2000).

The SFA model used in this article assumes the existence of technological inefficiency which is not constant over time but evolves following a particular behaviour.

We follow Kumbhakar et al. (1991) assuming

$$
y_{i}=\alpha+\boldsymbol{x}_{i} \beta+v_{i}-u_{i}
$$

and

$$
u_{i}=\gamma^{\prime} \mathbf{z}_{i}+\varepsilon_{i} ; \quad u_{i} \sim N^{+}\left(\mathbf{z}_{i} \gamma, \sigma_{u}^{2}\right)
$$

where $y_{i}$ is the output, $\boldsymbol{x}_{i}$ is the inputs vector and random noise in the production process is introduced through the first error component $v_{i} \sim$ iid $N\left(0, \sigma_{v}^{2}\right)$; the second error component $\left(u_{i}\right)$, which captures the effects of technological inefficiency, has a systematic component $\gamma^{\prime} z_{i}$ associated with the exogenous variables and a random component $\varepsilon_{i}$. Thus, the inefficiency effects in the frontier model have distributions that vary with $\boldsymbol{z}_{i}$ so they are no longer identically distributed $^{16}$. The model has been generalised to the panel data case by Battese and Coelli $(1992,1995)$.

Given these assumptions, it is then possible to define the log-likelihood function to be maximized with respect to parameters $\left(\beta, \gamma, \sigma_{v}^{2}, \sigma_{u}^{2}\right)$ and to obtain consistent estimates of all parameters ${ }^{17}$.

Once obtained maximum likelihood estimates of all parameters, technological efficiency has to be estimated for each of the $i_{s}^{\prime}$ observed production units.

Kumbhakar and Lovell (2000) refined the decomposition of TFP change, also accounting for time-varying scale effects and changes of allocative inefficiency over time, as follows. Consider the following production function:

$$
Y_{i t}=f\left(X_{i t}, t ; \beta\right) \exp \left(-u_{i t}\right)
$$

\footnotetext{
${ }^{13}$ A second measure of market liquidity used in the literature is value traded, defined as the value of trades of domestic shares on domestic exchanges divided by GDP. However, since financial markets are forward looking, value traded has one potential pitfall. If markets anticipate large corporate profits, stock prices will rise today. This price rise would increase the value of stock transactions and therefore raise value traded. Problematically, the liquidity indicator would rise without a rise in the number of transactions or a fall in transaction costs (Levine and Zervos, 1998).

${ }^{14}$ Tadesse (2007) employs total value traded instead of stock market turnover ratio. Demirguc-Kunt and Levine (2001) present measures using both value traded and stock market turnover ratio and find no different rankings.

15 Moreover, a country can move along the frontier by changing inputs.

16 The requirement that $u_{i} \geq 0$ requires that $\varepsilon_{i} \geq-\gamma^{\prime} z_{i}$, which does not require $\gamma^{\prime} z_{i} \geq 0$. However it is necessary to impose distributional assumptions on $v_{i}$ and $\varepsilon_{i}$, and to impose the restriction $\varepsilon_{i} \geq-\gamma^{\prime} z_{i}$, in order to derive the likelihood function.

17 Two alternative parameterizations of the log-likelihood function have been proposed by Aigner et al. (1977) and Battese and Corra (1977). Aigner et al. (1977) express the log-likelihood function in terms of the two parameters $\sigma^{2} \equiv \sigma_{\mathrm{u}}^{2}+\sigma_{\mathrm{v}}^{2}$ and $\lambda \equiv \sigma_{\mathrm{u}} / \sigma_{\mathrm{v}}$. On the other hand, Battese and Corra (1977) provide a parameterization of the log-likelihood function in terms of the variance parameter $\gamma \equiv \sigma_{u}^{2} / \sigma^{2}$. The latter parameterization of the $\log$-likelihood function allows an easy way of testing the frontier model (8) versus its non-frontier version (with no inefficiency effects). Indeed, the parameter $\gamma$ takes values between 0 and 1 , with $\gamma=0(\gamma=1)$ indicating that the deviations from the frontier are entirely due to statistical noise (technological inefficiency). For details on the test of the null hypothesis that $\mathrm{H}_{0}: \gamma=0$ (no scope for the frontier model), see Coelli et al. (1998).
} 
where $i=1, \ldots, N$ producers are observed over $t=1, \ldots, T$ years, $Y, f($.$) and \exp \left(-u_{i t}\right)$ are interpreted as above in this section and time is included as a regressor in the production function in order to capture technological change ${ }^{18}$. Omitting the $i$ and $t$ subscripts, taking logs and time derivatives:

$$
\dot{y}=\frac{\operatorname{dln} f(X, t)}{d t}-\frac{\partial u}{\partial t}
$$

Totally differentiating $\ln f(X, t)$ with respect to time:

$$
\frac{d \ln f(X, t)}{d t}=\frac{\partial \ln f(X, t)}{\partial t}+\sum_{j} \frac{\partial \ln f(X, t)}{\partial X_{j}} \cdot \frac{\partial X_{j}}{\partial t}=\frac{\partial \ln f(X, t)}{\partial t}+\sum_{j} \epsilon_{j} \cdot \dot{x}_{j}
$$

and replacing (6) in (5) is then possible to obtain the following decomposition of output growth:

$$
\dot{y}=\frac{\partial \ln f(X, t)}{\partial t}+\sum_{j} \epsilon_{j} \cdot \dot{x}_{j}-\frac{\partial u}{\partial t}
$$

where $\partial \operatorname{lnf}(X, t) / \partial \ln X_{j}$ defines the output elasticity $\epsilon_{j}$ of input $X_{j}$ at the frontier. Notice that equation (7) distinguishes three sources of output growth:

(i) $\quad \mathrm{TC}=\partial \operatorname{lnf}(\mathrm{X}, \mathrm{t}) / \partial \mathrm{t} \Rightarrow$ exogenous technological change. That is, given a certain inputs use, if $\mathrm{TC}>$ 0 (TC $<0)$, exogenous technological change shifts the production frontier upward (downward);

(ii) $\mathrm{EC}=-\partial \mathrm{u} / \partial \mathrm{t} \Rightarrow$ efficiency change. EC represents the rate at which an inefficient producer moves towards the frontier (technological efficiency declines over time if $\mathrm{EC}<0$ );

(iii) $\quad \sum_{\mathrm{j}} \epsilon_{\mathrm{j}} \cdot \dot{\mathrm{x}}_{\mathrm{j}} \Rightarrow$ change in input use. It is worth noting that if inputs quantities do not change over time, then $\dot{\mathrm{y}}=\mathrm{TC}+\mathrm{EC}$.

Kumbhakar and Lovell (2000) shows how to estimate the three components of TFP change in (7) in a Translog production frontier model under the two alternative assumptions (i) $\mathrm{v}_{\mathrm{i}} \sim \mathrm{N}\left(0, \sigma_{\mathrm{v}}^{2}\right)$ and (ii) $\mathrm{u}_{\mathrm{i}} \sim \mathrm{N}^{+}\left(\mathrm{z}_{\mathrm{i}} \gamma, \sigma_{\mathrm{u}}^{2}\right)$ (time-varying inefficiency effects hypothesis), using the following Translog production function:

$$
y_{i t}=\alpha_{0}+\sum_{j} \beta_{j} x_{j i t}+\beta_{t} t+\frac{1}{2} \sum_{j} \sum_{k} \beta_{j k} x_{j i t} x_{k i t}+\frac{1}{2} \beta_{t t} t^{2}+\sum_{j} \beta_{j t} x_{j i t} t+v_{i t-} u_{i t}
$$

The first variant of the model is based on the assumption that the temporal pattern of inefficiency is described by $u_{i}=\gamma^{\prime} z_{i}+\varepsilon_{i}$. Given this, provided that $u_{i} \sim N^{+}\left(z_{i} \gamma, \sigma_{u}^{2}\right), v_{i} \sim$ iid $N\left(0, \sigma_{v}^{2}\right)$ and that $v_{i t}$ are independent of $u_{i t}$ for any $i$ and $t$, it is possible to derive the log-likelihood function for (8) and to obtain maximum likelihood estimators of the technological parameters $(\beta)$ and all the parameters in $\gamma, \sigma_{\mathrm{v}}^{2}, \sigma_{\mathrm{u}}^{2}$. Finally, the technological component of TFP change for each producer at each point in time can be computed on the basis of the following estimate:

$$
T C=\beta_{t}+\beta_{t t} t+\sum_{j} \beta_{j t} x_{j}
$$

The technological change index between period $s$ and $t$ for the $i$-th country can be calculated directly from the estimated parameters. One first evaluates the partial derivatives of the production function with respect to time using the data for the $i$-th country in periods $s$ and $t$. Then the technological change index between the adjacent periods $s$ and $t$ is calculated as the geometric mean of these two partial derivatives. That is:

$$
\text { Technological change index }=\exp \left\{\frac{1}{2}\left[\frac{\partial \ln y_{i s}}{\partial s}+\frac{\partial \ln y_{i t}}{\partial t}\right]\right\}
$$

\footnotetext{
18 Technological change is not restricted to be neutral with respect to the inputs; neutrality requires that $\mathrm{f}\left(\mathrm{X}_{\mathrm{it}}, \mathrm{t} ; \beta\right)=A(t) \cdot g\left(X_{i t} ; \beta\right)$.
} 


\section{Data}

Our sample contains data for 27 OECD member countries (Australia, Austria, Belgium, Canada, Czech Republic, Denmark, Estonia, Finland, France, Germany, Greece, Hungary, Iceland, Ireland, Israel, Italy, Korea, the Netherlands, Norway, Poland, Portugal, Slovak Republic, Slovenia, Spain, Sweden, United Kingdom, United States) during the 1996-2010 period. Data are thoroughly described in the Appendix.

For the estimation of the technological change (TC), we estimate a Translog production function by running the equation [8] where the dependent variable $\left(y_{i t}\right)$ is the log of real GDP and the independent variables are the log of the labour force and physical capital $\left(\mathrm{x}_{\mathrm{ijt}}\right)$. The GDP and labour force data ${ }^{19}$ are from OECD STAN database for Industrial Analysis. Due to the lack of data on physical capital stock across the countries, we decided to follow the methodology of Dhareshwar and Nehru (1994), i.e. to estimate capital stock as summation of past gross investment flows ${ }^{20}$. The summary statistics for the explanatory variables are reported in Table A1.

As already showed in paragraph $\S 3.2$ we follow the SFA approach in order to estimate and decompose the "productivity change" in its two main components: efficiency change (EC) and technological change (TC). We adopt the model proposed by Battese and Coelli (1995) which assumes that inefficiency, $\left(u_{i t}\right)$ in the model, is not identically distributed for all units observed and all the time, but instead follows a truncated normal distribution, the mean of which varies from unit to unit and year to year, depending on a series of explanatory variables $\left(\boldsymbol{z}_{i}\right)$.

The explanatory variables for the efficiency term are human capital (Soderbom and Teal, 2001; De la Fuente, 2011) and institutional variables (Valeriani and Peluso, 2011). Human capital is measured as the percentage of labour force with tertiary education (taken from OECD statistics). As institutional variables we build on the Worldwide Governance Indicators database developed by D. Kauffman et al. (2010) as part of the World Bank's Governance Matter project ${ }^{21}$. The indicators measure six dimensions of governance: Voice and Accountability, Political Stability and Absence of Violence/Terrorism, Government Effectiveness, Regulatory Quality, Rule of Law, and Control of Corruption. The summary statistics for the efficiency explanatory variables are reported in Table A2.

In order to construct Market-Bank orientation (MB) we build on aggregate cross-country data extracted by the Global Financial Development Database ${ }^{22}$. As already recalled in paragraph $\$ 3.1$, we follow the approach of Tadesse (2007) and construct a continuous variable, $\mathrm{MB}$, which is the principal component of (i) market size, (ii) market activity and (iii) market efficiency. By construction, higher value of $\mathrm{MB}$ indicates a more market-oriented financial system. The summary statistics for the three variables used to build the MB variable are reported in Table A3.

With reference to Financial Structure (FS) variables we include: foreign banks among total banks, bank concentration ${ }^{23}$, bank lending-deposit spread, bank capitalization, stock price volatility and number of listed companies (see Table A4 for related summary statistics).

Macroeconomic Environment (ME) includes the following set of variables: lagged real GDP per capita growth, lagged output gap in percent of potential GDP, general government total expenditure and trade openness (see Table A5 for descriptive statistics).

\section{Econometric Results}

\subsection{Estimates of technological change}

As already recalled in section 3.2 the stochastic frontier model used in this paper assumes the existence of technological inefficiency $\left(u_{i t}\right)$ which evolves following a particular behaviour. This allows us to split productivity changes into (i) the change in technological efficiency, which measures the movement of an economy towards (or away from) the production frontier, and (ii) the technological change (or technological progress), which measures shifts of the frontier itself over time.

The parameter estimates for the Translog stochastic frontier production function are reported in Table 1; for robustness

\footnotetext{
${ }^{19}$ In particular, we use the civilian labour force which corresponds to total labour force excluding armed forces.

${ }^{20} \mathrm{~K}$ is constructed as: $\mathrm{K}_{\mathrm{t}}=\mathrm{K}_{\mathrm{t}-1}(1-\theta)+\mathrm{I}_{\mathrm{t}}$, where $\mathrm{K}$ is capital stock, I investment and $\theta$ the rate of depreciation. $\theta$ is assumed as 6 percent along the lines of Hall and Jones (1999) and Bernanke and Gurkaynak (2001). Initial capital stocks are constructed by the assumption that capital and output grow at the same rate. Specifically, for countries with investment data beginning in 1990 we set the initial capital stock $K_{1990}=I_{1990} /(g+\theta)$ where $g$ is the 10 year growth rate of output (e.g., from 1980 to 1990).

${ }^{21}$ See http://info.worldbank.org/governance/wgi/index.aspx\#home.

${ }^{22}$ The Global Financial Development Database is an extensive dataset of financial system characteristics for 203 economies. The database includes measures of (1) size of financial institutions and markets (financial depth), (2) degree to which individuals can and do use financial services (access), (3) efficiency of financial intermediaries and markets in intermediating resources and facilitating financial transactions (efficiency), and (4) stability of financial institutions and markets (stability).

${ }^{23}$ See Cetorelli and Gambera (2001) for more details on bank concentration.
} 
reasons we run four alternative models which mainly differ from each other for the list of efficiency explanatory variables used. A total of 8 out of the 9 coefficients (excluding the constant) comprised in the frontier function are significantly different from zero at the 5 percent level. The three direct effects, two of the squared terms and the three cross products have coefficients significantly different from zero.

The impact of labour is negative and significant in all the specifications. It might be thought that countries more specialized in labour-intensive industries are also those less involved in innovative, knowledge-intensive, more productive sectors; therefore a higher use of labour could suggest a lower potential (or predicted) output. Capital, as expected, affects positively and significantly the predicted output in all the specifications. The results are robust across the alternative specifications ${ }^{24}$.

As we apply the approach firstly proposed by Battese and Coelli (1995), which allows to remove some restrictive assumptions on the inefficiency distributional proprieties, we are able to investigate the determinants of inefficiency, i.e. the factors that exert an impact on our sample inefficiency ${ }^{25}$. The explanatory variables for the inefficiency term are (i) institutional variables and (ii) human capital.

In order to assess whether efficiency is related to better governance, we use several indicators of government effectiveness of the World Bank (see Kaufmann et al., 2008) and test their contribution to efficiency. As measure of human capital we use the percentage of the labour force with tertiary education (taken from OECD statistics). The results are reported in Table 1. Since inefficiency in equation (9) is measured in terms of the distance from the frontier, a negative impact indicates an increase in efficiency (i.e. catching up toward the frontier). Therefore, for instance, a positive effect of improved government effectiveness in increasing technological efficiency is represented by a negative coefficient.

Governance explanatory variables: Government Effectiveness, Regulatory Quality and Rule of Law are significantly different from zero and with the expected sign in all specification, while Political Stability, Voice and Accountability and Control of Corruption are not significant. These results confirm the well-known empirical evidence showing the strong correlation between good governance and growth across countries. There is now a growing understanding that economic, political, legal and social institutions are essential to the economic success and failure of nations (see Acemoglu and Robinson, 2012). Particularly important elements of governance include the regulation of economic institutions (represented in our model by Government Effectiveness, Regulatory Quality and Rule of Law) which may create incentives for investment and technology adoption, for its businesses to invest, and for its workers the opportunity to accumulate human capital, thus engendering economic growth.

Human capital: we see that the coefficient of Tertiary Education is statistically significant with negative sign in all the specification, except the fourth one, confirming the idea that a better educated labour force reduces inefficiency.

\footnotetext{
${ }^{24}$ As pointed out by Berger and Mester (1997) some cautions should be applied in interpreting the signs of estimated parameters of the Translog production function. The Translog function (as opposed to the Cobb Douglas one) is intended to estimate the theoretically optimal output given a set of inputs and it comprises linear, quadratic and multiplicative effects of each input of production function, so it's not straightforward the economic interpretation of coefficients.

${ }^{25}$ Since by construction the efficiency is equal to $E f f=(1-u)$, where u is the inefficiency, we can interpret the signs of explanatory variables as follow: a negative coefficient affects negatively the inefficiency (so increase the efficiency); a positive coefficient of explanatory variables affects positively the inefficiency (so decrease the efficiency).
} 
Table 1. Production Function Estimation Results

\begin{tabular}{|c|c|c|c|c|c|c|c|c|}
\hline & \multicolumn{2}{|c|}{ Model 1} & \multicolumn{2}{|c|}{ Model 2} & \multicolumn{2}{|c|}{ Model 3} & \multicolumn{2}{|c|}{ Model 4} \\
\hline & coefficient & $t$ ratio & coefficient & $t$ ratio & coefficient & $t$ ratio & coefficient & $t$ ratio \\
\hline \multicolumn{9}{|c|}{ Production Frontier } \\
\hline Constant & $-9,27$ & $-4,03$ & $-8,59$ & $-3,88$ & $-9,21$ & $-3,90$ & $-14,28$ & $-14,34$ \\
\hline Labour & $-1,14$ & $-2,29$ & $-1,06$ & $-2,05$ & $-1,16$ & $-2,14$ & $-5,28$ & $-5,82$ \\
\hline Capital & 2,70 & 6,07 & 2,58 & 5,90 & 2,70 & 5,71 & 5,07 & 9,99 \\
\hline Time & $-0,27$ & $-5,17$ & $-0,27$ & $-5,05$ & $-0,27$ & $-4,80$ & $-0,58$ & $-0,63$ \\
\hline Labor2 & $-0,05$ & $-0,80$ & $-0,04$ & $-0,66$ & $-0,05$ & $-0,79$ & $-0,64$ & $-1,52$ \\
\hline Capital2 & $-0,16$ & $-3,62$ & $-0,15$ & $-3,39$ & $-0,16$ & $-3,37$ & $-0,48$ & $-5,20$ \\
\hline Time2 & 0,00 & $-2,14$ & 0,00 & $-3,89$ & 0,00 & $-2,13$ & & \\
\hline Labour*Capital & 0,11 & 2,14 & 0,10 & 1,91 & 0,11 & 2,00 & 0,57 & 2,94 \\
\hline Capital*Time & 0,02 & 4,93 & 0,02 & 4,73 & 0,02 & 4,41 & 0,05 & 0,70 \\
\hline Labour*Time & $-0,02$ & $-4,12$ & $-0,02$ & $-3,83$ & $-0,02$ & $-3,58$ & $-0,05$ & $-0,87$ \\
\hline \multicolumn{9}{|c|}{ Inefficiency model } \\
\hline Constant & 1,45 & 5,78 & 1,53 & 6,93 & 1,46 & 5,79 & 0,32 & 0,32 \\
\hline Tertiary edu & $-0,04$ & $-6,88$ & $-0,04$ & $-7,75$ & $-0,04$ & $-6,42$ & $-0,01$ & $-0,10$ \\
\hline Voice and Accountability & $-0,30$ & $-1,42$ & $-0,35$ & $-1,80$ & $-0,30$ & $-1,43$ & 0,16 & 0,16 \\
\hline Political Stability & & & $-0,24$ & $-0,27$ & 0,06 & 0,10 & $-0,02$ & $-0,02$ \\
\hline Government effectiveness & $-1,05$ & $-4,97$ & $-1,15$ & $-6,02$ & $-1,05$ & $-5,28$ & $-0,33$ & $-0,35$ \\
\hline Regulatory Quality & $-0,17$ & $-0,96$ & $-0,21$ & $-0,96$ & $-0,17$ & $-0,93$ & $-0,20$ & $-0,20$ \\
\hline Rule of Law & $-0,82$ & $-3,49$ & $-1,04$ & $-4,73$ & $-0,79$ & $-3,17$ & $-0,28$ & $-0,29$ \\
\hline Control of Corruption & & & 0,38 & 1,55 & & & $-0,25$ & $-0,26$ \\
\hline & 0,13 & 6,99 & 0,15 & 8,82 & 0,13 & 6,53 & 0,17 & 0,37 \\
\hline & 0,93 & 63,21 & 0,94 & 80,55 & 0,93 & 61,61 & 0,93 & 12,40 \\
\hline Number of observations & 405 & & 405 & & 405 & & 405 & \\
\hline Log-likelihood & 159,77 & & 160,93 & & 159,89 & & 56,30 & \\
\hline
\end{tabular}

Note: The estimates in the first panel are the parameters of the Translog production function while the estimates in the second panel are the parameters of the inefficiency model. $\sigma^{2}$ is the estimate of the standard deviation of the statistical noise. $\gamma=\sigma_{u}^{2} / \sigma^{2}$. Coelli et al. (1998) point out that if $\gamma=0$, the deviations from the frontier are entirely due to noise. All the data are in percentage values.

Table 2 shows the estimated Technological change (TC) - which represents the shift of a country's frontier during the time period ranging from 1996 to 2010 - for a subsample of countries among our 27 OECD countries ${ }^{26}$. Germany, USA and Italy are the countries with the best technological innovation performance during the 90s: they attain the higher values of Technological change variables, respectively 1.87 for Germany and USA and 1.84 for Italy. France, Norway and Spain follow with 1.78, 1.43 and 1.04. Hungary experienced a serious delay due to its deep transition to an open market system (-2.24).

Italy seems to perform better till the early 2000s (2004-2005) when it significantly slowed and was overtaken by many countries: in 2005 France reached an annual technological change (TC) equal to 2.15, higher than the 2.14 of Italy. In the same year (2005) the distance between Italy and Germany which was very close in the first year (1.84 versus 1.87 in 1996) widened to almost 30 basis points (2.14 versus 2.41 in 2005). In 2010 countries with best performances are USA (2.96) and Germany (2.52), followed by France and Italy (2.44 and 2.29).

\footnotetext{
${ }^{26}$ We present the results for the four biggest countries in the Euro area, USA, a Scandinavian country (Norway) and a former transition economy (Hungary). The estimated $T C$ for the full list of countries and for the alternative models 2, 3 and 4 is showed upon request. There is a wide variation in economic performances across countries. Average rates of technological change range from $-3.1 \%$ per annum in Estonia to $2.5 \%$ per annum in the United States. Ranking countries by their average realized rates, we observe that, in general, in most advanced economies technological progress has been much faster than, for instance, in transition countries. This may be a signal of advanced countries' larger capacity to spur technological innovations.
} 
Table 2. Technological change (TC)

\begin{tabular}{|rrrrrrrr|}
\hline & \multicolumn{1}{c}{ Italy } & France & \multicolumn{1}{c}{ Germany } & Spain & Norway & USA & Hungary \\
\hline 1996 & 1,84 & 1,78 & 1,87 & 1,04 & 1,43 & 1,87 & $-2,24$ \\
\hline 1997 & 1,88 & 1,82 & 1,95 & 1,06 & 1,43 & 1,95 & $-2,13$ \\
\hline 1998 & 1,92 & 1,84 & 2,01 & 1,10 & 1,53 & 2,04 & $-2,01$ \\
\hline 1999 & 1,95 & 1,87 & 2,09 & 1,11 & 1,60 & 2,14 & $-1,95$ \\
\hline 2000 & 1,97 & 1,90 & 2,16 & 1,14 & 1,66 & 2,23 & $-1,87$ \\
\hline 2001 & 2,00 & 1,94 & 2,22 & 1,18 & 1,64 & 2,34 & $-1,76$ \\
\hline 2002 & 2,04 & 1,98 & 2,29 & 1,25 & 1,69 & 2,43 & $-1,63$ \\
\hline 2003 & 2,08 & 2,04 & 2,35 & 1,30 & 1,73 & 2,50 & $-1,56$ \\
\hline 2004 & 2,11 & 2,09 & 2,39 & 1,34 & 1,79 & 2,58 & $-1,44$ \\
\hline 2005 & 2,14 & 2,15 & 2,41 & 1,37 & 1,86 & 2,64 & $-1,32$ \\
\hline 2006 & 2,16 & 2,19 & 2,42 & 1,42 & 1,95 & 2,70 & $-1,22$ \\
\hline 2007 & 2,19 & 2,24 & 2,43 & 1,49 & 1,99 & 2,76 & $-1,12$ \\
\hline 2008 & 2,21 & 2,29 & 2,46 & 1,60 & 2,02 & 2,83 & $-0,99$ \\
\hline 2009 & 2,26 & 2,38 & 2,49 & 1,78 & 2,09 & 2,92 & $-0,92$ \\
\hline 2010 & 2,29 & 2,44 & 2,52 & 1,88 & 2,17 & 2,96 & $-0,85$ \\
\hline
\end{tabular}

Note: annual level of the estimated variable $T C$ expressed in percentage

Figure 1 plots the annual variation of TC for a subsample of countries. Indeed, it is important to consider not only the level but also the dynamics of Technological Change which provides useful insights on the speed of catching up in certain countries and on the prevailing stagnation path for others. Moving from the annual level of Technological change (TC) to the yearly and cumulative change of this variable we can shed light on some structural tendencies. The highest cumulative structural improvement in Technological change is that of Hungary $(-0.85+2.24=1.39)$ and the lowest is that of Italy $(2.29-1.84=0.45)$.
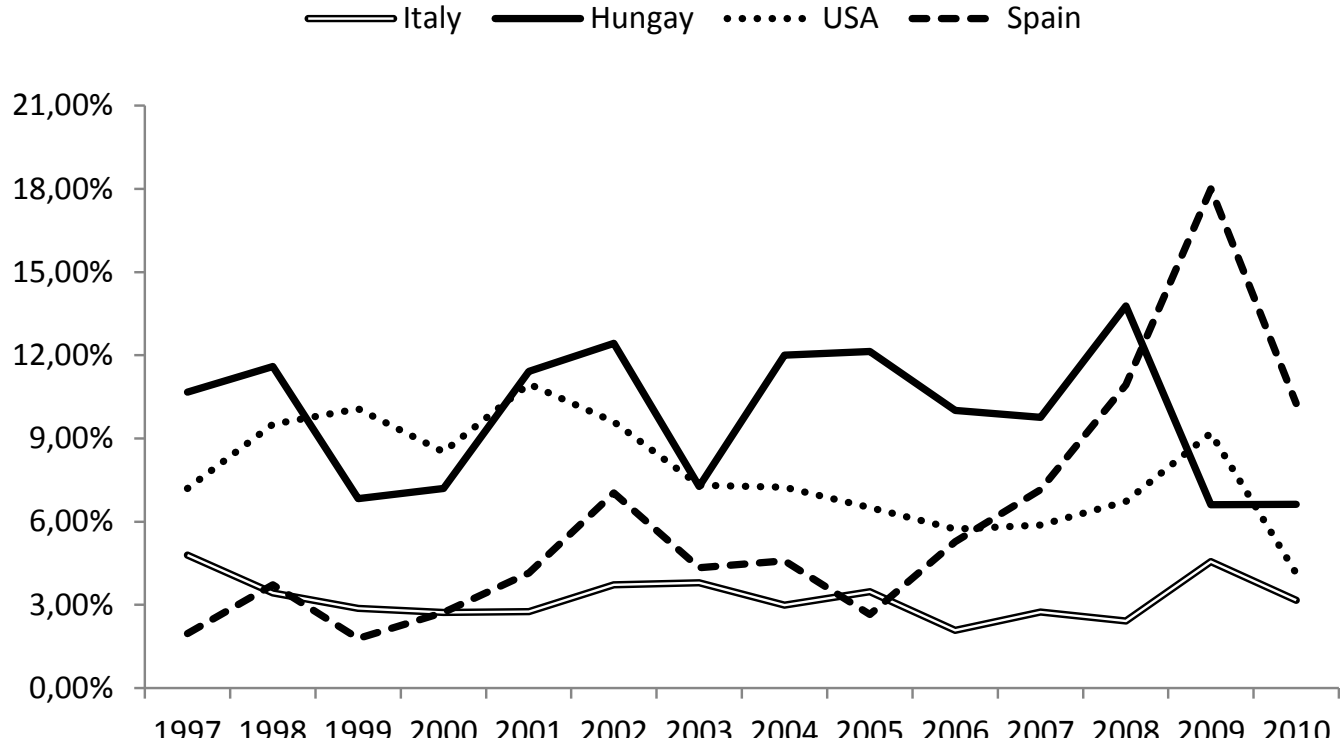

Figure 1. Annual variation of Technological Change 
Efficiency scores, showed in Table $3^{27}$, refer to the country's ability to reach the production frontier which means the distance between the actual output gained by a country (GDP), given a certain inputs endowment (Labour and Capital), and the maximum theoretical output that would have been reached given the technological parameters of production function. The variation of efficiency levels in time is a qualifying point of the econometric method chosen as the most common models used do not allow the evaluation of this variation (Battese and Coelli 1995) or only let to estimate the trend or convergence parameter of the system, thus hindering any analysis of the time dynamic of the single units observed. Efficiency changes represent the movements a country does towards or away from the frontier.

Norway is the country by far most efficient followed by USA. They perform better than other countries during the whole time period considered, whit a slight decrease of efficiency only during the last years (2006-2010), probably due to the recent financial crisis ${ }^{28}$.

France and Germany which start with an equivalent level of efficiency (92.10 and 92.35) in 1996 undertake two different paths: while France keeps to perform well till the onset of financial crisis (in 2008 the France's score was 94.53) and then declines to 91.58; German suffers a steady decrease during the nineties - probably due to the German industrial restructuring - and then it starts to rebuild its efficiency since 2004. A process that was abruptly interrupted by the insurgence of financial crisis in 2008.

Hungary shows the most impressive improvement in its efficiency score, ranging from 62.09 in 1996 to 80.62 in 2010 , partly due to the well-known high speed catching up effect which benefits less developed-follower countries. Italy and Spain lag behind other countries and experienced a decrease in score efficiency respectively by roughly 6 and 10 percentage points (Italy shifts from 88.53 to 82.77 and Spain from 89.48 to 79.99 ). They seem to be affected by a relentless decline which becomes more pronounced starting from 2002-2003.

Table 3. Efficiency scores

\begin{tabular}{|c|c|c|c|c|c|c|c|}
\hline & Italy & France & Germany & Spain & Norway & USA & Hungary \\
\hline 1996 & 88,53 & 92,10 & 92,35 & 89,48 & 97,77 & 95,63 & 62,09 \\
\hline 1997 & 88,33 & 92,02 & 92,13 & 89,17 & 97,79 & 96,61 & 63,21 \\
\hline 1998 & 87,61 & 92,76 & 91,45 & 89,16 & 97,78 & 96,77 & 65,12 \\
\hline 1999 & 86,85 & 92,77 & 91,21 & 88,67 & 97,78 & 96,82 & 66,11 \\
\hline 2000 & 87,08 & 92,83 & 91,38 & 88,44 & 97,87 & 96,76 & 67,42 \\
\hline 2001 & 86,54 & 92,50 & 91,03 & 87,87 & 97,81 & 96,61 & 69,22 \\
\hline 2002 & 85,35 & 92,19 & 90,54 & 87,45 & 97,82 & 96,60 & 71,38 \\
\hline 2003 & 84,04 & 92,01 & 86,68 & 86,62 & 97,79 & 96,60 & 72,98 \\
\hline 2004 & 84,31 & 94,34 & 90,44 & 81,06 & 97,94 & 96,70 & 76,00 \\
\hline 2005 & 83,93 & 92,89 & 90,52 & 80,12 & 97,99 & 96,72 & 78,19 \\
\hline 2006 & 84,34 & 94,62 & 90,95 & 79,91 & 98,00 & 96,65 & 80,66 \\
\hline 2007 & 84,78 & 92,67 & 91,33 & 80,01 & 97,96 & 96,63 & 80,92 \\
\hline 2008 & 83,68 & 94,53 & 86,73 & 79,92 & 97,82 & 96,55 & 82,42 \\
\hline 2009 & 80,87 & 91,15 & 88,48 & 79,52 & 97,70 & 95,22 & 78,68 \\
\hline 2010 & 82,77 & 91,58 & 86,09 & 79,99 & 97,69 & 95,69 & 80,62 \\
\hline
\end{tabular}

Note: the scores are in percentage, so 100 means that the country is on the frontier and therefore reaches a maximum efficiency.

\subsection{Robustness check}

We check to see if our results are robust to a partially different sample, including a smaller number of countries for a longer period (1996-2011). Data for robustness check are also from OECD STAN database for Industrial Analysis. Table 4 presents the estimate results obtained on the restricted sample: (i) the initial rate of technological change (TC), (ii) the country ranking based on the initial value of technological change; (iii) cumulative growth rate of technological change between the initial year, $t$, and the final year of the sample, $T$; (iv) the country ranking speed based on

\footnotetext{
${ }^{27}$ Efficiency scores of the alternative models 2, 3 and 4 can be sent by authors upon request.

28 Norway achieves its maximum score in 2006 (98.00) while USA in 2005 (96.72).
} 
cumulative growth rate of $\mathrm{TC}^{29}$. As far as initial country ranking is concerned, we do not observe significant differences with respect to the baseline sample: Norway and Finland confirm their primacy. What is more interesting is the cumulative growth rate of technological change (TC) in the considered period: Hungary and Czech Republic confirm their success in the transition process with cumulative rates higher than $9 \%$. In the last positions of the ranking, we find Italy and Belgium, whose performance with reference to technological change (and hence innovation) has been poor as indicated by a cumulative growth rate of technological change lower than $3 \%$.

Italy slips back from the $6^{\text {th }}$ position in 1996 to the $9^{\text {th }}$ one in 2011, even worse does Belgium which moves back from the $3^{\text {th }}$ position in 1996 to the last one in 2011.

Table 4. Robustness check

\begin{tabular}{|c|c|c|c|}
\hline $\begin{array}{c}\text { Rate of technological } \\
\text { change in } t=1\end{array}$ & Country ranking & $\begin{array}{l}\text { Cumulative growth rate of } \\
\text { technological innovation } \\
\text { (between } t \text { and } T \text { ) }\end{array}$ & Country ranking speed \\
\hline 6,88 & Norway & 9,23 & Hungary \\
\hline 6,44 & Finland & 9,13 & Czech Republic \\
\hline 6,31 & Belgium & 8,01 & Denmark \\
\hline 6,08 & Austria & 7,34 & Unitet States \\
\hline 5,30 & Denmark & 6,58 & Sweden \\
\hline 4,77 & Italy & 5,28 & Norway \\
\hline 4,60 & Sweden & 3,16 & Austria \\
\hline 2,27 & Czech Republic & 2,92 & Finland \\
\hline 2,25 & United States & 2,87 & Italy \\
\hline 1,83 & Hungary & 2,41 & Belgium \\
\hline
\end{tabular}

Note: All the data are in percentage values.

\subsection{Estimating the impact of financial architecture on technological change}

To investigate the impact of financial architecture (FA) on technological change (TC) we run country fixed-effects ${ }^{30}$ unbalanced panel regressions both in good times (2002-2007) and crisis periods (1998-2010) [Eq. 1]. Due to the fact that the 1998-2010 period includes two financial crisis - the dot-com crisis in 2001 and the biggest financial crisis since the second world war from 2008 to 2010 - our model implemented in the whole period cannot perform properly. Indeed, financial variables are strongly affected by two different breaks caused by the crisis as shown by Figure B1 in the Appendix. Therefore, we concentrate on good times.

Table 5 shows results that are robust across several panel data specifications, in good times, i.e. between 2002 and 2007 and for 25 countries $^{31}$. A larger role of financial architecture (FA) variables seems to be clearly associated with higher levels of technological change (TC): both the positive sign and statistical significance of the coefficients of Market-Bank orientation (MB) and many of the variables comprised in the Financial Structure (FS) are unchanged across different specifications.

Estimated coefficients for MB (Market-Bank orientation) are always positive and statistically significant which means that a more market oriented financial system spurs innovation technology. Therefore our results seem to confirm the expected higher effectiveness of market-oriented financial systems in allocating resources to innovative firms which operate on the technological frontier ${ }^{32}$. On the contrary, bank-oriented financial systems are more focused on the incumbents firms, specialized on the mature industrial sector.

\footnotetext{
${ }^{29}$ Full results are available upon request.

${ }^{30}$ We perform the Hausman specification test in order confirm our theoretical preference for a fixed-effects model (we believe that country differences matter and are persistent along time). The Hausman test rejects the hypothesis that difference in coefficients are not systematic with a p-value $=0.000$ (Chi2 test statistic $=48.42)$ so confirming our choice.

${ }^{31}$ Australia, Austria, Belgium, Canada, Czech Republic, Estonia, Finland, France, Germany, Greece, Hungary, Iceland, Ireland, Israel, Italy, Korea, the Netherlands, Norway, Poland, Portugal, Slovak Republic, Spain, Sweden, United Kingdom, United States.

${ }^{32}$ More market-oriented financial system are deemed to deploy a positing role in fostering technological innovation also because well-developed market infrastructures tend to encourage venture capital firms (Black and Gilson, 1998).
} 
Table 5. Fixed-effects panel estimation in good times (2002-2007)

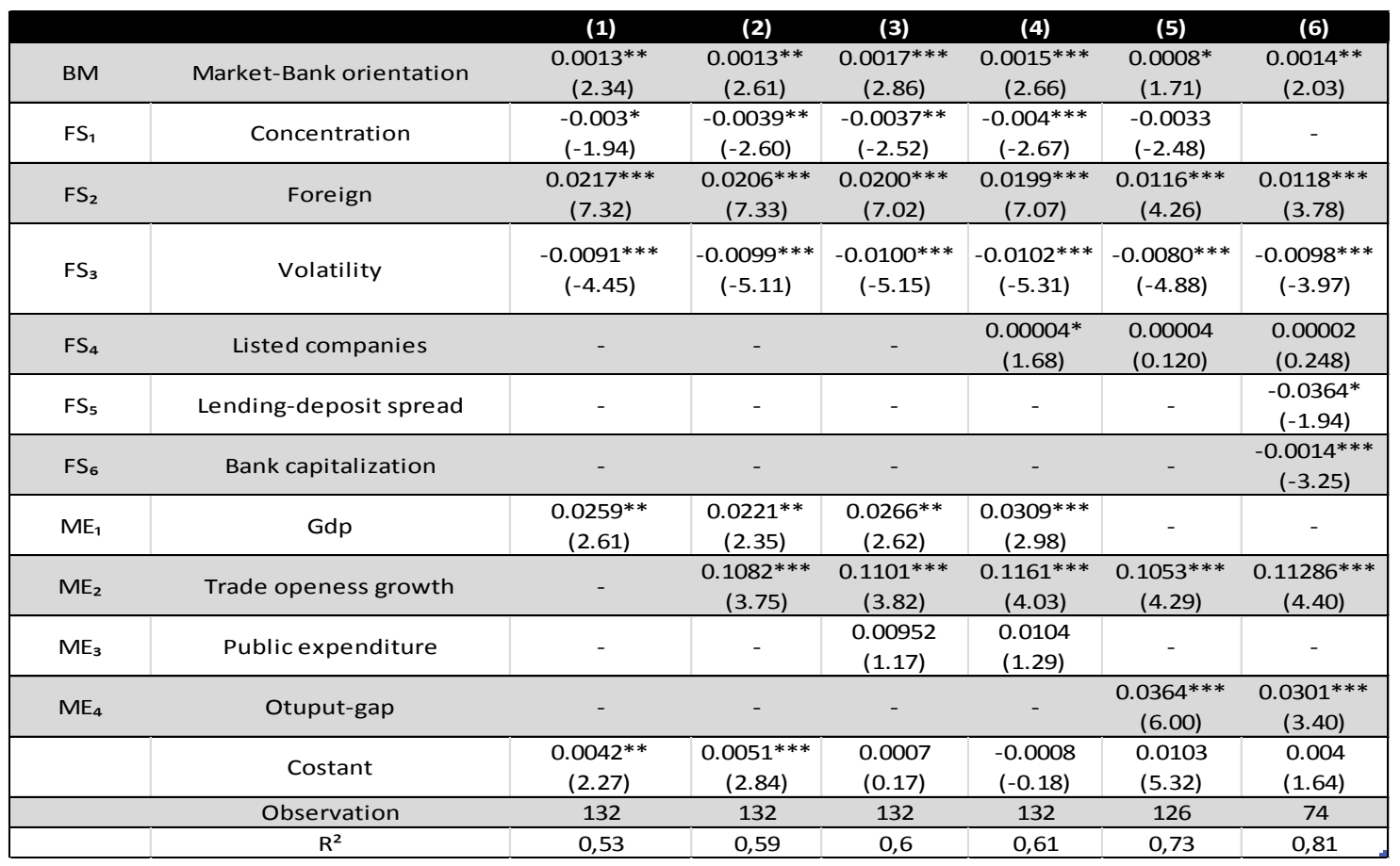

Note:***significant at $99 \%$; **significant at $95 \%$; significant at $90 \%$.

Higher concentration $\left(\mathrm{FS}_{1}\right)$ and lending spreads $\left(\mathrm{FS}_{5}\right)$, both indicators of the degree of competitiveness in the banking sector, are statistically significantly associated with lower technological change. One explanation is that higher spreads and higher concentration - either showing a degree of market power exerted by banks in a monopolistic market - enable banks to earn higher profits without competing for the best projects, and as a result they may be less motivated to take risk financing riskier and more innovative firms who mostly affect the country's technological innovation.

A larger share of foreign banks $\left(\mathrm{FS}_{2}\right)$ in the domestic banking sector is positively associated with higher technological change. This result, which is robust through the different specifications, signals that higher levels of financial globalization may be associated with more technological progress. A higher presence of foreign banks in a domestic market could boost technological change in two ways: (i) foreign banks which enter a domestic market try to gain market share by financing more opaque and riskier firms that are characterized by innovative and high return project investment (firms mostly constrained by domestic banks); (ii) a financial system which shows a non-negligible presence of foreign banks is likely to be well interconnected with a broader financial and industrial area and therefore could easily absorb technological innovation from more advanced economies (via Foreign Direct Investment, international trade, etc.).

In other term, openness may also refer to the beneficial effects of playing in larger markets, which spurs innovation and promotes the adoption of new technologies from abroad. The impact in not unambiguous, however. It depends on a range of factors including an economy's factor endowment, the complementarities that exist between these and its production technologies and the correlation of shocks between the domestic and world economies (Grossman and Helpman, 1991).

Bank capitalization $\left(\mathrm{FS}_{6}\right)$ is negatively associated with technological change, suggesting that an excessive level of capital buffers may hinder the lending activities and therefore the financing of technological progress. Again, borrowing firms specialized on more innovative technology are those with riskier project and therefore their lending exposures absorb more banks' prudential capital.

Stock price volatility $\left(\mathrm{FS}_{3}\right)$ affects negatively technological progress. One explanation is that an increase in stock market volatility raises the compensation that shareholders demand for bearing idiosyncratic risks. Hence, the cost of equity increases and as a result the investments in technological progress - which are mostly funded by market - are negatively affected.

A higher number of listed companies $\left(\mathrm{FS}_{4}\right)$ is positively, though not always significantly, associated with technological progress, indicating the importance of having a well-developed domestic capital market. More easily innovative firms can go public more entrepreneurial projects will succeed, with technological spill over effects on the whole economy. 
Macroeconomic environment variables (ME) are GDP, output gap, public expenditure and trade openness growth. GDP $\left(\mathrm{ME}_{1}\right)$ shows the expected positive sign in all specifications and is always statistically significant: countries with higher per capita GDP growth are those with higher speed in technological change reflecting a wider availability of resources devoted to investments in knowledge-intensive sectors ${ }^{33}$. Output gap $\left(\mathrm{ME}_{4}\right)$, which has the same economic meaning of GDP, is estimated in alternative of GDP and presents always the right sign and maximum statistical significance.

Public expenditure $\left(\mathrm{ME}_{3}\right)$ expected to affects positively the technological change. It is envisioned as an extra-input in the countries' production function, which is the complementary effect exerted by governments in providing private sector with public goods like infrastructures, educations, public research, etc. The variable presents the right sign (positive) but is never significant, probably due to the fact that in the national accounting standard the gross variable public expenditure is overwhelmed by the current expenditure component which doesn't refer to the public R\&D activities or other infrastructural investments which are those solely related to technological change.

When we include data up to 2011, i.e. all the years of the so-called big crisis, we lose most of the results obtained in good times. Market-Bank orientation (MB), output gap, concentration and volatility maintain the sign but lose statistical significance. Trade openness growth, which was positive in good times, becomes negative, even if not significant: this may signal that a higher level of international integration is associated with poor outcomes during crisis periods, due to the higher contagion pulses countries absorb from abroad (Gentile and Giordano, 2013). A larger capital buffer is negatively associated with technological progress indicating the potential problems related to pro-cyclical effects of capital requirements. Table 6 shows the results only for one model specification. Full results are available upon request.

We also run the equation [1] by adding time dummy variables in order to take into account the effect of common shocks on technological change exerted by different phases of economic cycle.

Table 7 shows that MB variable loses significance and among the FS variables those which still hold significance are Foreign $\left(\mathrm{FS}_{2}\right)$, Lend-Deposit spreads $\left(\mathrm{FS}_{5}\right)$, Bank Capitalization $\left(\mathrm{FS}_{6}\right)$, Public Expenditure $\left(\mathrm{ME}_{3}\right)$ and Output Gap $\left(\mathrm{ME}_{4}\right)$. All the significant variables are with the right sign.

These results confirm that more open and competitive financial system are conducive for technological change. The specification with time dummies also confirms that the higher the bank capitalization the lower the propensity to finance innovative project which are more capital absorbing. Public Expenditure and Output Gap exert the expected beneficial effect on TC.

Table 6. Fixed-effects panel estimation in the whole sample, including bad times (1998-2010)

\begin{tabular}{|c|ccccc|}
\hline $\mathrm{BM}$ & Market-Bank orientation & $\begin{array}{c}0.0018 \\
(1.39)\end{array}$ & $\mathrm{FS}_{1}$ & Concentration & $\begin{array}{c}-0.0036 \\
(-0.97)\end{array}$ \\
\hline $\mathrm{FS}_{2}$ & Foreign & $\begin{array}{c}0.0181^{* * *} \\
(3.98)\end{array}$ & $\mathrm{FS}_{3}$ & Volatility & $\begin{array}{c}-0.0001 \\
(0.01)\end{array}$ \\
\hline $\mathrm{FS}_{4}$ & Bank capitalization & $\begin{array}{c}-0.1319^{* * *} \\
(-4.27)\end{array}$ & $\mathrm{FS}_{5}$ & Listed companies & $\begin{array}{c}-0.0001 \\
(-1.28)\end{array}$ \\
\hline $\mathrm{ME}_{1}$ & Trade openness growth & $\begin{array}{c}-0.0575 \\
(-1.50)\end{array}$ & $\mathrm{ME}_{2}$ & Output gap & $\begin{array}{c}-0.165 \\
(-1.50)\end{array}$ \\
\hline & Constant & $\begin{array}{c}0.0118^{* *} \\
(2.28)\end{array}$ & & Observations \\
\hline
\end{tabular}

Note:***significant at $99 \%$; **significant at $95 \%$; significant at $90 \%$.

The lack of significance of MB and other few FS variables could be attributed to the prevailing influence of time trend on technological change, particularly in a relative short period of time as that one we used for calculation. Indeed, it might suggest that FA (financial architecture) do have some not negligible effect in spurring technological progress but perhaps it takes longer time before deploying a detectable effect. The overall R squared sharply increased compared to the previous estimation.

33 Although we are aware that an unsolvable endogeneity problem exists. 
Table 7. Fixed-effects panel estimation in good times (2002-2007), with time dummies

\begin{tabular}{|c|c|c|c|c|c|c|c|}
\hline & Specification with time dummy variables & (1) & (2) & (3) & (4) & (5) & (6) \\
\hline BM & Market-Bank orientation & $\begin{array}{c}0.00 \\
(-0.94)\end{array}$ & $\begin{array}{c}0.00 \\
(-0.89)\end{array}$ & $\begin{array}{c}0.00 \\
(0.11)\end{array}$ & $\begin{array}{c}0.00 \\
(0.07)\end{array}$ & $\begin{array}{c}0.00 \\
(-0.17)\end{array}$ & $0.00(-1.17)$ \\
\hline $\mathrm{FS}_{1}$ & Concentration & $\begin{array}{l}0.001 \\
(-1.24)\end{array}$ & $\begin{array}{c}0.001 \\
(-1.26)\end{array}$ & $\begin{array}{l}-0.001 \\
(-1.09)\end{array}$ & $\begin{array}{l}-0.001 \\
(-1.18)\end{array}$ & $0.00(-0.73)$ & - \\
\hline $\mathrm{FS}_{2}$ & Foreign & $\begin{array}{c}0.013 \\
(5.89)^{* * *}\end{array}$ & $\begin{array}{c}0.135 \\
(5.85)^{* * *}\end{array}$ & $\begin{array}{c}0.123 \\
(5.40)^{* * *}\end{array}$ & $\begin{array}{c}0.123 \\
(5.42)^{* * *}\end{array}$ & $\begin{array}{c}0.01 \\
(4.30)^{* * *}\end{array}$ & $\begin{array}{c}0.11 \\
(4.45)^{* * *}\end{array}$ \\
\hline $\mathrm{FS}_{3}$ & Volatility & $\begin{array}{l}0.002 \\
(1.07)\end{array}$ & $\begin{array}{l}0.002 \\
(0.96)\end{array}$ & $\begin{array}{l}0.002 \\
(1.35)\end{array}$ & $0.002(1.21)$ & $0.002(0.95)$ & $\begin{array}{c}0.00 \\
(0.09) \\
\end{array}$ \\
\hline $\mathrm{FS}_{4}$ & Listed companies & - & - & - & $0.00(0.81)$ & $\begin{array}{c}0.00 \\
(0.91) \\
\end{array}$ & $\begin{array}{c}0.00 \\
(0.29) \\
\end{array}$ \\
\hline $\mathrm{FS}_{5}$ & Lending-deposit spread & - & - & - & - & - & $\begin{array}{c}-0.048 \\
(-2.89)^{* * *}\end{array}$ \\
\hline $\mathrm{FS}_{6}$ & Bank capitalization & - & - & - & - & - & $\begin{array}{c}-0.036 \\
(-3.49)^{* * *}\end{array}$ \\
\hline $\mathrm{ME}_{1}$ & Gdp & $\begin{array}{c}0.00 \\
(-0.04)\end{array}$ & $\begin{array}{c}0.00 \\
(-0.06)\end{array}$ & $\begin{array}{l}0.008 \\
(0.99)\end{array}$ & $\begin{array}{c}0.01 \\
(1.18)\end{array}$ & - & - \\
\hline $\mathrm{ME}_{2}$ & Trade openess growth & - & $\begin{array}{l}0.016 \\
(0.52) \\
\end{array}$ & $\begin{array}{l}0.017 \\
(0.58) \\
\end{array}$ & $\begin{array}{l}0.021 \\
(0.68) \\
\end{array}$ & $\begin{array}{l}0.021 \\
(0.71) \\
\end{array}$ & $\begin{array}{l}0.024 \\
(0.72) \\
\end{array}$ \\
\hline $\mathrm{ME}_{3}$ & Public expenditure & - & - & $\begin{array}{c}0.017 \\
(2.82)^{* * *}\end{array}$ & $\begin{array}{c}0.017 \\
(2.85)^{* * *}\end{array}$ & - & - \\
\hline $\mathrm{ME}_{4}$ & Otuput-gap & - & - & & - & $\begin{array}{c}0.021 \\
(2.98)^{* * *}\end{array}$ & $\begin{array}{l}0.007 \\
(0.89)\end{array}$ \\
\hline & Costant & $\begin{array}{c}0.004 \\
(2.96)^{* * *}\end{array}$ & $0.004(2.98)^{* * *}$ & $\begin{array}{l}-0.003 \\
(-1.23)\end{array}$ & $\begin{array}{l}-0.004 \\
(-1.36)\end{array}$ & $\begin{array}{c}0.004 \\
(3.06)^{* * *}\end{array}$ & $\begin{array}{c}0.003 \\
(2.10)^{* *}\end{array}$ \\
\hline & Observation & 132 & 132 & 132 & 132 & 132 & 132 \\
\hline & $\mathrm{R}^{2}$ & 0,77 & 0,77 & 0,79 & 0,79 & 0.81 & 0.91 \\
\hline
\end{tabular}

Note:***significant at $99 \%$; **significant at $95 \%$; significant at $90 \%$. Time dummies always significant at $1 \%$ level.

As additional robustness check, we run the Equation [1] by taking first order lagged variables on the right hand side. We do that as a way to alleviate potential endogeneity relationship which could feed back the TC change into explanatory variables (Langfield and Pagano, 2015).

Table 8. Fixed-effects panel estimation in good times (2002-2007), with lagged variables

\begin{tabular}{|c|c|c|c|c|c|c|c|}
\hline & Specification with lagged variables & (1) & (2) & (3) & (4) & (5) & (6) \\
\hline $\mathrm{BM}$ & Market-Bank orientation (-1) & $\begin{array}{l}-0.0003 \\
(-0.77) \\
\end{array}$ & $\begin{array}{l}0.0001 \\
(0.29) \\
\end{array}$ & $\begin{array}{l}0.0001 \\
(0.30) \\
\end{array}$ & $\begin{array}{l}0.0001 \\
(0.30) \\
\end{array}$ & $\begin{array}{l}0.0001 \\
(-0.38) \\
\end{array}$ & $\begin{array}{c}0.0013 \\
(-2.71)^{* * *}\end{array}$ \\
\hline $\mathrm{FS}_{1}$ & Concentration (-1) & $\begin{array}{l}-0.002 \\
(-1.28) \\
\end{array}$ & $\begin{array}{c}-0.003 \\
(-2.32)^{* *}\end{array}$ & $\begin{array}{c}-0.003 \\
(-2.31)^{* *}\end{array}$ & $\begin{array}{c}-0.003 \\
(-2.41)^{* *}\end{array}$ & $\begin{array}{c}-0.003 \\
(-2.19)^{* *}\end{array}$ & - \\
\hline $\mathrm{FS}_{2}$ & Foreign (-1) & $\begin{array}{c}0.019 \\
(6.84)^{* * *}\end{array}$ & $\begin{array}{c}0.017 \\
(6.60)^{* * *} \\
\end{array}$ & $\begin{array}{c}0.017 \\
(6.39)^{* * *}\end{array}$ & $\begin{array}{c}0.017 \\
(6.38)^{* * *} \\
\end{array}$ & $\begin{array}{c}0.014 \\
(4.58)^{* * *} \\
\end{array}$ & $\begin{array}{c}0.007 \\
(2.13)^{* *} \\
\end{array}$ \\
\hline $\mathrm{FS}_{3}$ & Volatility $(-1)$ & $\begin{array}{c}-0.013 \\
(-7.22)^{* * *}\end{array}$ & $\begin{array}{c}-0.013 \\
(-8.80)^{* * *}\end{array}$ & $\begin{array}{c}-0.013 \\
(-7.77)^{* * *}\end{array}$ & $\begin{array}{c}-0.013 \\
(-7.58)^{* * *}\end{array}$ & $\begin{array}{c}-0.011 \\
(-6.66)^{* * *}\end{array}$ & $\begin{array}{c}-0.011 \\
(-4.75)^{* * *}\end{array}$ \\
\hline $\mathrm{FS}_{4}$ & Listed companies $(-1)$ & - & - & - & $\begin{array}{l}0.000 \\
(0.75) \\
\end{array}$ & $\begin{array}{r}0.000 \\
(0.65) \\
\end{array}$ & $\begin{array}{r}0.000 \\
(0.93) \\
\end{array}$ \\
\hline $\mathrm{FS}_{5}$ & Lending-deposit spread (-1) & - & - & - & - & - & $\begin{array}{c}-0.061 \\
(-3.09)^{* * *} \\
\end{array}$ \\
\hline $\mathrm{FS}_{6}$ & Bank capitalization $(-1)$ & - & - & - & - & - & $\begin{array}{c}-0.044 \\
(-3.42)^{* * *}\end{array}$ \\
\hline $\mathrm{ME}_{1}$ & $\operatorname{Gdp}(-1)$ & $\begin{array}{c}-0.017 \\
(-2.27)^{* *}\end{array}$ & $\begin{array}{l}-0.006 \\
(-0.97) \\
\end{array}$ & $\begin{array}{l}-0.006 \\
(-0.91) \\
\end{array}$ & $\begin{array}{r}-0.005 \\
(-0.67) \\
\end{array}$ & - & - \\
\hline $\mathrm{ME}_{2}$ & Trade openess growth $(-1)$ & - & $\begin{array}{c}0.135 \\
(5.24)^{* * *}\end{array}$ & $\begin{array}{c}0.135 \\
(5.18)^{* * *}\end{array}$ & $\begin{array}{c}0.136 \\
(5.18)^{* * *}\end{array}$ & $\begin{array}{c}0.158 \\
(6.30)^{* * *}\end{array}$ & $\begin{array}{c}0.177 \\
(6.11)^{* * *}\end{array}$ \\
\hline $\mathrm{ME}_{3}$ & Public expenditure (-1) & - & - & $\begin{array}{l}0.005 \\
(0.07) \\
\end{array}$ & $\begin{array}{l}0.005 \\
(0.07) \\
\end{array}$ & - & - \\
\hline $\mathrm{ME}_{4}$ & Otuput-gap (-1) & - & - & - & - & $\begin{array}{c}0.024 \\
(2.71)^{* * *} \\
\end{array}$ & $\begin{array}{r}0.010 \\
(1.05) \\
\end{array}$ \\
\hline & Costant & $\begin{array}{c}0.007 \\
(4.12)^{* * *}\end{array}$ & $\begin{array}{c}0.008 \\
(2.25)^{* *} \\
\end{array}$ & $\begin{array}{c}0.008 \\
(2.25)^{* *} \\
\end{array}$ & $\begin{array}{c}0.008 \\
(2.14)^{* *} \\
\end{array}$ & $\begin{array}{c}0.008 \\
(5.14)^{* * *}\end{array}$ & $\begin{array}{c}0.009 \\
(3.94)^{* * *}\end{array}$ \\
\hline & Observation & 130 & 130 & 130 & 130 & 124 & 84 \\
\hline & $R^{2}$ & 0.54 & 0.64 & 0,64 & 0,64 & 0.68 & 0.78 \\
\hline
\end{tabular}

Table 8 shows that MB orientation variable loses significance expect that in the last specification (column 6). Comparing Table 5, 6 and 7 we cannot reach a robust evidence on the superiority of market-oriented financial system in boosting technological change.

Other main conclusions drawn from the basic model still hold: i) Concentration ( $\left.\mathrm{FS}_{1}\right)$ and Lending-deposit spreads $\left(\mathrm{FS}_{5}\right)$ are good proxies for market competitiveness and highlight that more competitive financial system drives credit 
suppliers (either through banks or market) to compete for the most profitable projects and hence improve resource allocation; ii) widespread presence of foreign banks $\left(\mathrm{FS}_{2}\right)$ boosts $\mathrm{TC}$ since foreign institutions are well suited vehicles in absorbing innovation from abroad; iii) volatility $\left(\mathrm{FS}_{3}\right)$ increases the risk remuneration required by investors and hence reduce the propensity to fund innovative projects ; iv) bank capitalization $\left(\mathrm{FS}_{6}\right)$ increases the cost of funds for riskier firms.

Macroeconomic variables (ME) perform with the expected sing and significance as well: trade openness growth $\left(\mathrm{ME}_{2}\right)$ speeds up TC by increasing the exchange of knowledge and by leveraging on foreign direct investment; Output Gap $\left(\mathrm{ME}_{4}\right)$ shows the usual beneficial effect on market environment, either in term of tangible and intangible infrastructure and in term of expectations.

\section{Conclusions}

Since the beginning of the global financial crisis many structural changes - including crisis intervention measures and evolving regulatory reform agenda - have occurred in the financial system. The changing structures for financial intermediation can be expected to affect economic growth, its volatility and financial stability. However, while there is a quite extensive literature analysing the relation between financial development (generally measured by the size of the financial system) and growth, less theoretical and empirical work exists on the effect of financial structure on several dimensions of economic performance: resilience to financial crisis (stability), technological change, income inequality, competitiveness, social mobility, etc.

Two financial systems can allocate the same amount of resources but the way they do it (the features of financial system) affects seriously the final output, particularly from a social desirability perspective. Only measuring the size or depth of financial systems allows getting a rough idea of what are the underlying forces in places in spurring long-run growth, especially for advanced economies.

From a policy point of view, it is crucial to understand how different financial structures have interacted with economic outcomes in the past in order to assess the expected changes probably resulting by the evolving reforming agenda.

In this paper we contribute to this literature by exploring the impact of financial architecture (FA) on technological change (TC). The hypothesis we test is whether a larger role of financial markets with respect to banks is associated with a higher rate of technological change. Doing this, we address the key determinant of growth, i.e. technological progress that crucially determines the success of an economy. There is a lot of empirical evidence clearly showing that economies characterised by higher level of technological progress have generally more competitive and globalized companies and, as a result, higher GDP growth rates and lower unemployment levels. This is particularly important for mature economies of advanced countries challenged by the competition from emerging markets.

We find that a well-functioning domestic capital market has a positive and significant effect on technological progress: financial systems with higher presence of foreign banks, more competitive (less concentrated and with lower bank spreads), with higher companies' propensity to go public and less volatile stock market, are those economies which experience a higher technological progress. We find mixed evidence on the role of market-bank orientation of financial system on technological change.

From a policy point of view, our results are particularly relevant given the recent so called Capital Markets Union (CMU) proposal at the EU level. CMU project aims to create a more balanced financial structure in the EU enhancing the flow of capital to European investment prospects from the EU and the rest of the world and channel it to all companies, including SMEs, infrastructures and long-term projects; improving risk transfer and allocation of capital across the EU, to increase the probability that capital flows where it is needed; and diversifying sources of funding by expanding risk finance and making Europe less reliant on bank lending and more resilient to shocks.

\section{References}

Acemoglu, D., \& Robinson, J. (2012) Why nations fail, Crown Publishing Group.

Aigner, D., Knox, L. C. A., \& Schmidt, P. (1977) Formulation and estimation of stochastic frontier production function models, Journal of Econometrics, 6, 21-37. http://dx.doi.org/10.1016/0304-4076(77)90052-5

Allen, F. (1993). Stock market and resource allocation, in Capital Market and Financial Intermediaries, Colin Mayer and Xavier Vives (eds.), Cambridge University Press. http://dx.doi.org/10.1017/CBO9780511752056.007

Allen, F., \& Douglas, G. (2000). Comparing Financial Systems, MIT Press. 
Battese, G. E., \& Coelli, T. J. (1992). Frontier production functions, technological efficiency and panel data: with application to paddy farmers in India, The Journal of Productivity Analysis, 3, 153-169. http://dx.doi.org/10.1007/BF00158774

Battese, G. E., \& Coelli, T. J. (1995) A Model for Technological Inefficiency Effects in a Stochastic Frontier Production Function for Panel Data, Empirical Economics, 20, 325-332. http://dx.doi.org/10.1007/BF01205442

Battese, G. E., \& Corra. (1977) Estimation of a production frontier model: with application to the pastoral zone of eastern Australia, The Australian Journal of Agricultural and Resource Economics, 21, 169-179. http://dx.doi.org/10.1111/j.1467-8489.1977.tb00204.x

Beck, T. A., Demirguk-Kunt, R. L., \& Maksimovic, V. (2000) Financial structure and economic development: firm, industry and country evidence, World Bank Policy Research Working Paper, 2423.

Berger, A. N. (1995). The profit-structure relationship in banking: Tests of mark-et-power and efficient-structure hypotheses, Journal of Money, Credit and Banking. http://dx.doi.org/10.2307/2077876

Berger, A., \& Mester, L. J. (1997) Inside the black box: What explains differences in the efficiencies of financial institutions?, Journal of Banking and Finance, 21(7), 895-947. http://dx.doi.org/10.1016/S0378-4266(97)00010-1

Bernanke, B., \& Gurkaynak, R. (2001) Is growth exogenous? Taking Mankiw, Romer and Weil seriously, NBER Macroeconomics Annual,16, 11-57. http://dx.doi.org/10.1086/654431

Black, B. S., \& Ronald, J. G.(1998), Venture capital and the structure of capital markets: Banks versus stock markets, Journal of Financial Economics, 47(3), 243-277. http://dx.doi.org/10.1016/S0304-405X(97)00045-7

Caballero, R. J., Hoshi, T., \& Kashyap, A. K. (2008), Zombie lending and depressed restructuring in Japan, American Economic Review, 98(5), 1943-1977. http://dx.doi.org/10.1257/aer.98.5.1943

Carlin, W., \& Mayer, C. (2003) Finance, investment, and growth, Journal of Financial Economics, 69, $191-226$. http://dx.doi.org/10.1016/S0304-405X(03)00112-0

Cetorelli, N., \& Gambera, M. (2001). Banking market structure, financial dependence and growth: International evidence from industry data. The Journal of Finance, 56(2), 617-648. http://dx.doi.org/10.1111/0022-1082.00339

Chakraborty, S., \& Ray, T. (2006) Bank-based versus market-based financial systems: A growth-theoretic analysis, Journal of Monetary Economics, 53(2), 329-350. http://dx.doi.org/10.1016/j.jmoneco.2005.01.003

Claessens, S., \& Horen, N. V. (2012) Foreign Banks: Trends, Impact and Financial Stability, IMF Working Paper. $\mathrm{WP} / 12 / 10$.

Coelli, T, D., Prasada, R., \& Battese, G. (1998) An introduction to efficiency and productivity analysis, Kluver Academic Publisher. http://dx.doi.org/10.1007/978-1-4615-5493-6

Dela, F. A. (2011). Human Capital and Productivity, Barcelona Economics Working Paper Series, Working Paper 530.

DeMasi, P. (1997) IMF Estimates of Potential Output: Theory and Practice, in Staff Studies for the World Economic Outlook.

Demsetz, H. (1973), Industry Structure, Market Rivalry, and Public Policy, Journal of Law and Economics, 16(1). http://dx.doi.org/10.1086/466752

Dewatripont, M., \& Maskin, E. (1995), Credit and efficiency in centralized and decentralized economies, Review of Economic Studies, 62, 541-555. http://dx.doi.org/10.2307/2298076

Dhareshwar, A., \& Nehru,V. (1994) New estimates of total factor productivity growth for developing and industrial countries The World Bank Policy Research Working Paper Series, 1313.

Disney, R., Haskel, J., \& Heden, Y. (2003). Restructuring and productivity growth in UK manufacturing, Economic Journal, 113(489), 666-694. http://dx.doi.org/10.1111/1468-0297.t01-1-00145

García-Herrero, A., \& Cuadro, S. L. (2008) Finance for Growth: Does a Balanced Financial Structure Matter, Revue Economique, 59(6), 1075-1096. http://dx.doi.org/10.3917/reco.596.1075

Gentile, M., \& Giordano, L. (2013) Financial Contagion during Crises: A Comparison between Sovereign Bond and Stock Markets, Journal of Financial Management Markets and Institutions, 2, 197-224.

Gole, T., \& Sun, T. (2013) Financial structures and economic outcomes: an empirical analysis, IMF WP/13/121.

Grossman, G., \& Helpman, E. (1991). Innovation and growth in the global economy, MIT Press.

Hall, R. E., \& Jones, C. I. (1999). Why do some countries produce so much more output per worker than others?, Quarterly Journal of Economics, 114(1), 83-116. http://dx.doi.org/10.1162/003355399555954 
Hsu, P. H., Tian, X., \& Xu, Y. (2014) Financial development and innovation: Cross-country evidence, Journal of Financial Economics, 112(1), 116-135. http://dx.doi.org/10.1016/j.jfineco.2013.12.002

IMF (2012). Global Financial Stability Report, October Issue.

Kaserer, C., \& Rapp, M. S. (2014).Capital markets and economic growth: long-term trends and policy challenges, AIMA Research Report.

Kauffman, D., Kraay, A., \& Mastruzzi, M. (2010). The worldwide governance indicators: methodology and analytical issues, World Bank Policy Research Working Paper 5430.

Knight, F. (1921). Risk, Uncertainty and Profit, The Riverside Press, Cambridge, MA.

Koop, G. J., Osiewalski, M. F., \& Steel, J. (2000). Modeling the sources of output growth in a panel of countries, Journal of Business \& Economic Statistics, 18, 284-299.

Kumbhakar, S. C., \& Knox, L. C. A. (2000). Stochastic Frontier Analysis, Cambridge University Press. http://dx.doi.org/10.1017/CBO9781139174411

Kumbhakar, S., Gosh, S., \& McGuckin, J. T. (1991). A Generalized Production Frontier Approach for Estimating Determinants of Inefficiency in United-States Dairy Farms. Journal of Business and Economic Statistics, 279-286.

Langfield, S., \& Pagano, M. (2015). Bank bias in Europe: effects on systemic risk and growth, WP n. 1797, ECB.

Levine, R. (2002). Bank-based or market-based ?nancial systems: Which is better?, Journal of Financial Intermediation, 11, 398-428. http://dx.doi.org/10.1006/jfin.2002.0341

Peek, J., \& Rosengren, E. S. (2005). Unnatural selection: Perverse incentives and the misallocation of credit in Japan, American Economic review, 95(4), 1144-1166. http://dx.doi.org/10.1257/0002828054825691

Rajan, R. G., \& Ramcharan, R. (2015). The anatomy of credit crisis: the boom and bust in farm land prices in the United states in the 1920s, American Economic Review, 105(4), 1439-77. http://dx.doi.org/10.1257/aer.20120525

Soderbom, M., \& Teal, F. (2001). Firm size and human capital as determinants of productivity and earnings, Working Paper 2011-09, Oxford University.

Stigler, G. J. (1964). A Theory of Oligopoly, The Journal of Political Economy, 72(1). http://dx.doi.org/10.1086/258853

Tadesse, S. (2002). Financial architecture and economic performance: international evidence, Journal of financial intermediation, 11(4), 429-454. http://dx.doi.org/10.1006/jfin.2002.0352

Tadesse, S. A. (2007). Innovation, Information and Financial Architecture, Journal of Financial and Quantitative Analysis, 41(4),753-786.

Valeriani, E., \& Peluso, S. (2011). The Impact Of Institutional Quality On Economic Growth And Development: An Empirical Study, Journal of Knowledge Management, Economics and Information Technology, 6. 


\section{Appendix}

The dataset

Table A1. Data description for Technological change estimation ${ }^{1}$

\begin{tabular}{|c|c|c|c|c|c|c|}
\hline \multicolumn{2}{|r|}{ GDP } & \multicolumn{2}{|c|}{ Capital Stock } & \multicolumn{2}{|c|}{ Labour force } & \\
\hline & mean & sd & mean sd & sd & mean & sd \\
\hline Australia & 501.0 & 111.6 & 4.81 & 1.10 & $9,119.1$ & $1,162.3$ \\
\hline Austria & 220.8 & 30.9 & 2.99 & 0.89 & $3,759.4$ & 186.2 \\
\hline Belgium & 274.5 & 34.2 & 3.10 & 0.47 & $4,012.6$ & 280.6 \\
\hline Canada & 816.8 & 150.7 & 3.85 & 0.78 & $14,774.5$ & $1,566.4$ \\
\hline Czech Rep. & 90.9 & 17.7 & 2.85 & 0.46 & $4,817.0$ & 102.4 \\
\hline Denmark & 178.7 & 22.1 & 4.07 & 0.66 & $2,696.6$ & 80.1 \\
\hline Estonia & 8.2 & 3.0 & 11.08 & 3.49 & 639.5 & 75.1 \\
\hline Finland & 135.4 & 24.7 & 2.22 & 1.03 & $2,309.9$ & 148.4 \\
\hline France & $1,554.6$ & 177.9 & 3.05 & 0.48 & $24,404.9$ & 1338.8 \\
\hline Germany & $2,115.8$ & 183.8 & 3.57 & 1.66 & $36,128.0$ & $1,926.6$ \\
\hline Greece & 163.6 & 30.8 & 6.87 & 1.66 & $4,097.5$ & 315.2 \\
\hline Hungary & 81.5 & 12.0 & 5.38 & 0.84 & $3,815.9$ & 179.6 \\
\hline Iceland & 14.2 & 2.4 & 8.01 & 2.23 & 152.8 & 14.5 \\
\hline Ireland & 114.4 & 53.3 & 8.43 & 1.11 & $1,609.4$ & 347.7 \\
\hline Israel & 92.3 & 21.3 & 4.53 & 2.40 & $2,255.5$ & 356.9 \\
\hline Italy & $1,333.9$ & 107.5 & 2.44 & 0.75 & $21,383.4$ & $1,105.2$ \\
\hline Korea & 612.7 & 176.4 & 7.36 & 3.73 & $21,308.5$ & $1,772.4$ \\
\hline Netherlands & 460.5 & 70.3 & 3.68 & 0.71 & $7,584.9$ & 784.9 \\
\hline Norway & 204.0 & 35.5 & 3.05 & 1.22 & $2,214.2$ & 177.5 \\
\hline Poland & 209.4 & 57.7 & 11.66 & 3.77 & $14,877.0$ & 713.2 \\
\hline Portugal & 139.4 & 18.1 & 4.40 & 1.64 & $4,826.6$ & 296.9 \\
\hline Slovak Rep. & 41.9 & 11.7 & 5.53 & 1.35 & $2,186.7$ & 112.3 \\
\hline Slovenia & 24.2 & 5.6 & -4.35 & 0.94 & 912.3 & 45.6 \\
\hline Spain & 774.5 & 144.1 & 4.94 & 1.05 & $15,674.9$ & $2,909.9$ \\
\hline Sweden & 245.2 & 42.0 & 8.23 & 2.09 & $4,226.1$ & 220.9 \\
\hline UK & $1,508.4$ & 278.7 & 4.99 & 0.90 & $27,132.3$ & $1,366.1$ \\
\hline US & $9,033.5$ & $1,665.7$ & 4.35 & 1.33 & $132,773.8$ & $9,337.1$ \\
\hline
\end{tabular}

${ }^{1}$ Euro billions. ${ }^{2}$ Average rate of growth of capital stock between 1990 and 2010. ${ }^{3}$ Thousands of Civilian Labour. Force which corresponds to total labour force excluding armed forces. 
Table A2. Explanatory Variables

\begin{tabular}{|c|c|c|}
\hline a. Ffficiency term & & \\
\hline Variable & Short explanation & Source \\
\hline Tertiary education & It is the proportion of labor force that has a tertiary education, as a percentage of the total labor force. & $\begin{array}{l}\text { World Bank (World Development Indicators } \\
\text { database) }\end{array}$ \\
\hline Voice and accountability & $\begin{array}{l}\text { Reflects perceptions of the extent to which a country's citizens are able to participate in selecting their } \\
\text { government, as well as freedom of expression, freedom of association, and a free media. } \\
\text { It ranges from approximately }-2.5 \text { (weak) to } 2.5 \text { (strong) governance performance }\end{array}$ & WGI database \\
\hline $\begin{array}{l}\text { Political Stability and Absence of } \\
\text { violence /Terrorism }\end{array}$ & $\begin{array}{l}\text { Reflects perceptions of the likelihood that the government will be destabilized or overthrown by } \\
\text { unconstitutional or violent means, including politically-motivated violence and terrorism. } \\
\text { It ranges from approximately }-2.5 \text { (weak) to } 2.5 \text { (strong) governance performance }\end{array}$ & WGI database \\
\hline Government effectiveness & $\begin{array}{l}\text { Reflects perceptions of the quality of public services, the quality of the civil service and the degree of its } \\
\text { independence from political pressures, the quality of policy formulation and implementation, and the } \\
\text { credibility of the government's commitment to such policies. } \\
\text { It ranges from approximately }-2.5 \text { (weak) to } 2.5 \text { (strong) governance performance }\end{array}$ & WGI database \\
\hline Regulatory quality & $\begin{array}{l}\text { Reflects perceptions of the ability of the government to formulate and implement sound policies and } \\
\text { regulations that permit and promote private sector development. } \\
\text { It ranges from approximately }-2.5 \text { (weak) to } 2.5 \text { (strong) governance performance. }\end{array}$ & WGI database \\
\hline Rule of law & $\begin{array}{l}\text { Reflects perceptions of the extent to which agents have confidence in and abide by the rules of society, and in } \\
\text { particular the quality of contract enforcement, property rights, the police, and the courts, as well as the } \\
\text { likelihood of crime and violence. } \\
\text { It ranges from approximately }-2.5 \text { (weak) to } 2.5 \text { (strong) governance performance). }\end{array}$ & WGI database \\
\hline Control of corruption & $\begin{array}{l}\text { Reflects perceptions of the extent to which public power is exercised for private gain, including both petty and } \\
\text { grand forms of corruption, as well as "capture" of the state by elites and private interests. } \\
\text { It ranges from approximately }-2.5 \text { (weak) to } 2.5 \text { (strong) governance performance. }\end{array}$ & WGI database \\
\hline b. Financial Structure & & \\
\hline Variable & Short explanation & Source \\
\hline
\end{tabular}

Foreign banks Foreign banks among total banks: the percentage of the number of foreign owned banks over the number of the total banks in an economy.
World Bank (Global Financial Development database)
Stock price volatility

Number of listed companies

number of listed companies: number of domestically incorporated companies listed on the country's stock exchanges at the end of the year per $1,000,000$
World Bank (Global Financial Development database)

bank capitalization: ratio of bank capital and reserves to total assets. Capital and reserves include funds contributed by owners, retained earnings, general and special reserves, provisions, and valuation adjustments. Total assets include all nonfinancial and financial assets.
World Bank (Global Financial Development database) stock price volatility: the average of the 360 -day volatility of the national stock market index 
c. Macroeconomic environment

Variable

Source

GDP

lagged real GDP per capita growth

IMF (World Economic Outlook)

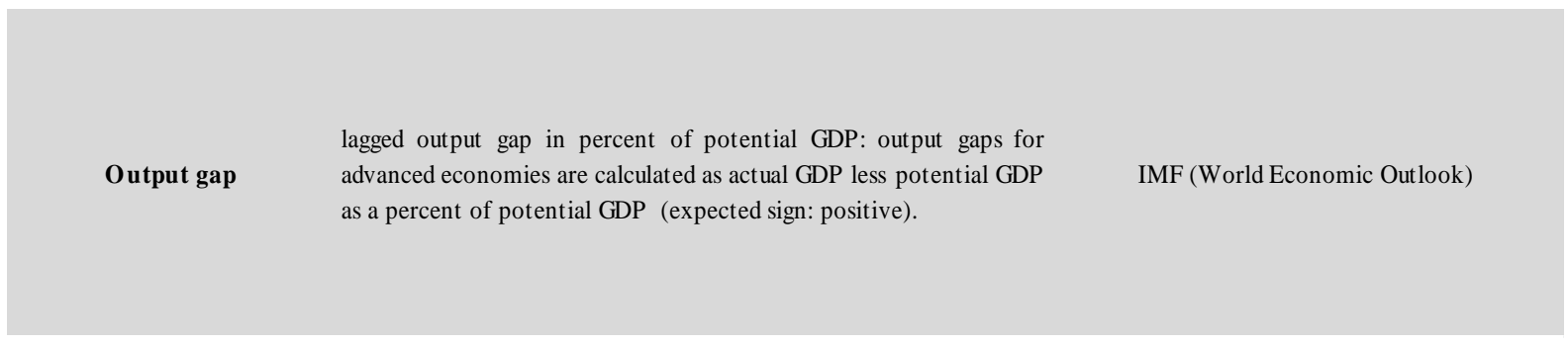

General government total expenditure

general government total expenditure: it consists of total expense and the net acquisition of nonfinancial assets (expected sign: uncertain).
IMF (World Economic Outlook)

trade openness growth: it is the annual variation of trade openness, calculated as total trade, i.e. the sum of exports and imports of

Trade openness growth goods and services, relative to GDP. We use the annual variation instead of the annual level since it could better proxy the dynamics IMF (World Economic Outlook) of countries' trade integration which is a long term phenomenon with several grades of stickiness (expected sign: positive). 
Table A3. Data description for Financial Architecture

\begin{tabular}{|c|c|c|c|c|c|c|c|c|}
\hline & Archit & e size & Architect & ctivity & Architectur & ciency & Financial a & ecture \\
\hline & mean & st dev & mean & st dev & mean & st dev & mean & st dev \\
\hline Australia & 1.106 & 0.163 & 0.796 & 0.175 & 0.011 & 0.006 & 1.135 & 0.160 \\
\hline Austria & 0.226 & 0.127 & 0.099 & 0.074 & 0.006 & 0.003 & 0.193 & 0.115 \\
\hline Belgium & 0.838 & 0.212 & 0.316 & 0.125 & 0.004 & 0.001 & 0.671 & 0.156 \\
\hline Canada & 0.991 & 0.218 & 0.720 & 0.177 & 0.016 & 0.006 & 1.024 & 0.185 \\
\hline $\begin{array}{l}\text { Czech } \\
\text { Republic }\end{array}$ & 0.598 & 0.183 & 0.370 & 0.190 & 0.014 & 0.007 & 0.579 & 0.222 \\
\hline Denmark & 0.580 & 0.483 & 0.607 & 0.606 & 0.009 & 0.002 & 0.720 & 0.657 \\
\hline Estonia & 0.494 & 0.284 & 0.155 & 0.180 & 0.009 & 0.016 & 0.380 & 0.223 \\
\hline Finland & 1.910 & 1.285 & 1.693 & 0.773 & 0.008 & 0.003 & 2.160 & 1.080 \\
\hline France & 0.872 & 0.203 & 0.781 & 0.229 & 0.010 & 0.002 & 0.995 & 0.225 \\
\hline Germany & 0.427 & 0.082 & 0.522 & 0.184 & 0.016 & 0.004 & 0.584 & 0.139 \\
\hline Greece & 1.050 & 0.830 & 0.682 & 0.772 & 0.014 & 0.005 & 1.032 & 0.955 \\
\hline Hungary & 0.653 & 0.318 & 0.541 & 0.319 & 0.035 & 0.015 & 0.732 & 0.376 \\
\hline Iceland & 0.535 & 0.223 & 0.338 & 0.265 & 0.010 & 0.007 & 0.521 & 0.260 \\
\hline Ireland & 0.431 & 0.267 & 0.215 & 0.138 & 0.002 & 0.002 & 0.379 & 0.228 \\
\hline Israel & 0.844 & 0.255 & 0.438 & 0.178 & 0.012 & 0.004 & 0.758 & 0.244 \\
\hline Italy & 0.510 & 0.243 & 0.579 & 0.219 & 0.027 & 0.012 & 0.673 & 0.259 \\
\hline Korea, Rep. & 0.757 & 0.218 & 1.619 & 0.455 & 0.034 & 0.012 & 1.486 & 0.356 \\
\hline Netherlands & 0.694 & 0.303 & 0.855 & 0.351 & 0.012 & 0.009 & 0.945 & 0.355 \\
\hline Norway & 0.707 & 0.163 & 0.715 & 0.280 & 0.015 & 0.004 & 0.863 & 0.271 \\
\hline Poland & 0.762 & 0.245 & 0.293 & 0.109 & 0.015 & 0.005 & 0.620 & 0.193 \\
\hline Portugal & 0.308 & 0.111 & 0.208 & 0.102 & 0.010 & 0.006 & 0.311 & 0.125 \\
\hline $\begin{array}{l}\text { Slovak } \\
\text { Republic }\end{array}$ & 0.141 & 0.057 & 0.034 & 0.033 & 0.011 & 0.015 & 0.107 & 0.033 \\
\hline Slovenia & 0.415 & 0.148 & 0.062 & 0.032 & 0.005 & 0.004 & 0.273 & 0.091 \\
\hline Spain & 0.627 & 0.163 & 1.034 & 0.352 & 0.005 & 0.004 & 1.020 & 0.314 \\
\hline Sweden & 1.443 & 0.979 & 1.563 & 0.590 & 0.015 & 0.003 & 1.820 & 0.896 \\
\hline $\begin{array}{l}\text { United } \\
\text { Kingdom }\end{array}$ & 0.940 & 0.340 & 0.965 & 0.286 & 0.018 & 0.010 & 1.156 & 0.211 \\
\hline $\begin{array}{l}\text { United } \\
\text { States }\end{array}$ & 2.433 & 0.538 & 4.372 & 1.250 & 0.060 & 0.021 & 4.214 & 0.769 \\
\hline
\end{tabular}

Source: calculations on Global Financial Development Database, World Bank. 
Table A4 Financial Structure Variables

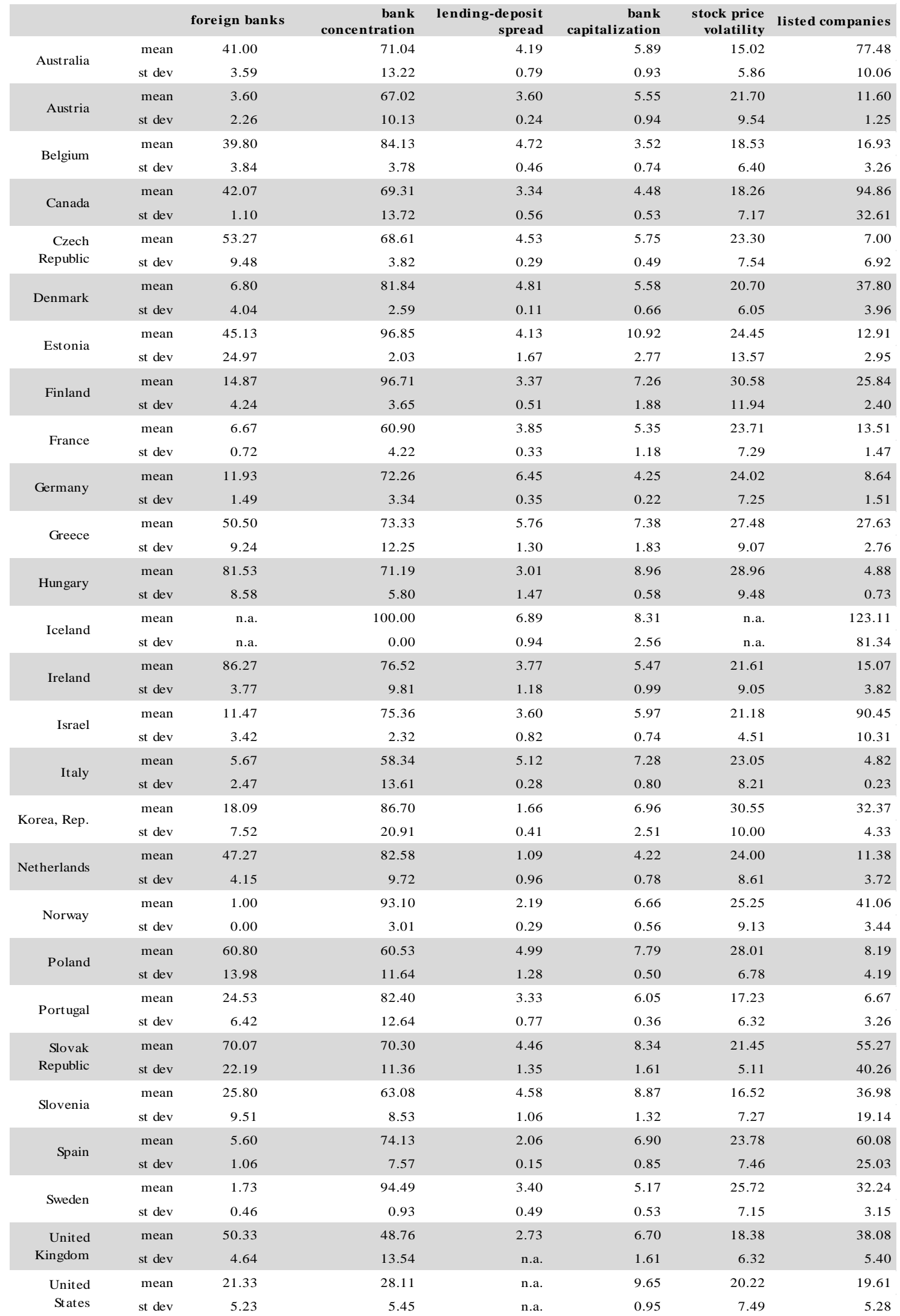

Source: calculations on Global Financial Development Database, World Bank. 
Table A5 Macroeconomic Environment Variables

\begin{tabular}{|c|c|c|c|c|c|}
\hline & & GDP per capita & Output gap & $\begin{array}{l}\text { General government } \\
\text { expenditure }\end{array}$ & Trade openness \\
\hline \multirow{2}{*}{ Aust ralia } & mean & 2.11 & 0.07 & 35.02 & 2.49 \\
\hline & st dev & 1.18 & 0.54 & 1.41 & 0.57 \\
\hline \multirow{2}{*}{ Austria } & mean & 1.71 & 0.07 & 51.92 & 6.56 \\
\hline & st dev & 2.01 & 1.69 & 2.26 & 1.34 \\
\hline \multirow{2}{*}{ Belgium } & mean & 1.43 & 0.09 & 50.46 & 13.95 \\
\hline & st dev & 1.83 & 1.16 & 1.63 & 3.01 \\
\hline \multirow{2}{*}{ Canada } & mean & 1.55 & 0.32 & 41.49 & 4.72 \\
\hline & st dev & 2.05 & 1.78 & 2.55 & 0.39 \\
\hline \multirow{2}{*}{$\begin{array}{c}\text { Czech } \\
\text { Republic }\end{array}$} & mean & 2.85 & 0.72 & 43.30 & 5.03 \\
\hline & st dev & 3.22 & 2.97 & 2.26 & 2.13 \\
\hline \multirow{2}{*}{ Denmark } & mean & 0.97 & 0.24 & 55.04 & 6.43 \\
\hline & st dev & 2.46 & 1.84 & 2.48 & 1.05 \\
\hline \multirow{2}{*}{ Estonia } & mean & 5.71 & 0.58 & 37.17 & 5.80 \\
\hline & st dev & 7.10 & 6.31 & 4.21 & 1.36 \\
\hline \multirow{2}{*}{ Finland } & mean & 2.44 & 0.82 & 51.70 & 5.88 \\
\hline & st dev & 3.67 & 2.70 & 3.79 & 0.96 \\
\hline \multirow{2}{*}{ France } & mean & 1.09 & -0.54 & 53.51 & 4.03 \\
\hline & st dev & 1.76 & 1.84 & 1.49 & 0.49 \\
\hline \multirow{2}{*}{ Germany } & mean & 1.06 & -0.30 & 47.03 & 5.15 \\
\hline & st dev & 2.13 & 1.64 & 1.70 & 1.09 \\
\hline \multirow{2}{*}{ Greece } & mean & 2.62 & 1.71 & 46.57 & 2.48 \\
\hline & st dev & 2.33 & 4.83 & 3.02 & 1.09 \\
\hline \multirow{2}{*}{ Hungary } & mean & 2.63 & 0.69 & 49.32 & 5.36 \\
\hline & st dev & 3.11 & 2.89 & 1.68 & 1.86 \\
\hline \multirow{2}{*}{ Iceland } & mean & 2.35 & & 44.64 & 5.55 \\
\hline & st dev & 3.73 & & 2.30 & 1.15 \\
\hline \multirow{2}{*}{ Ireland } & mean & 3.85 & 0.81 & 38.26 & 9.17 \\
\hline & st dev & 5.21 & 2.86 & 8.72 & 0.68 \\
\hline \multirow{2}{*}{ Israel } & mean & 1.65 & & 47.96 & 3.83 \\
\hline & st dev & 2.43 & & 3.50 & 0.57 \\
\hline \multirow{2}{*}{ Italy } & mean & 0.45 & 0.71 & 48.67 & 3.38 \\
\hline & st dev & 2.30 & 1.73 & 1.74 & 0.67 \\
\hline \multirow{2}{*}{ Korea, Rep. } & mean & 3.79 & & 19.58 & 3.85 \\
\hline & st dev & 3.90 & & 2.41 & 0.85 \\
\hline \multirow{2}{*}{ Netherlands } & mean & 1.82 & 0.24 & 46.81 & 10.18 \\
\hline & st dev & 2.24 & 1.64 & 2.06 & 2.22 \\
\hline \multirow{2}{*}{ Norway } & mean & 1.62 & 0.32 & 44.27 & 5.70 \\
\hline & st dev & 1.99 & 1.25 & 2.99 & 0.80 \\
\hline & mean & 4.54 & 0.64 & 44.25 & 2.59 \\
\hline Poland & st dev & 1.95 & 2.14 & 2.29 & 1.01 \\
\hline & mean & 1.45 & 0.22 & 44.41 & 3.54 \\
\hline Portugal & st dev & 2.24 & 1.51 & 3.00 & 0.56 \\
\hline Slovak & mean & 4.33 & 0.92 & 33.89 & 4.83 \\
\hline Republic & st dev & 3.79 & 2.61 & 4.48 & 2.42 \\
\hline & mean & 3.28 & 0.75 & 42.17 & 6.68 \\
\hline Slovenia & st dev & 3.68 & 3.19 & 2.08 & 1.75 \\
\hline & mean & 1.84 & 0.54 & 40.69 & 3.01 \\
\hline Spain & st dev & 2.29 & 2.10 & 2.73 & 0.46 \\
\hline & mean & 1.96 & 0.48 & 55.47 & 6.21 \\
\hline Sweden & st dev & 2.75 & 2.15 & 3.36 & 0.94 \\
\hline United & mean & 1.96 & 1.03 & 55.47 & 3.52 \\
\hline Kingdom & st dev & 2.60 & 1.78 & 3.36 & 0.33 \\
\hline United & mean & 1.51 & -0.37 & 55.47 & 1.58 \\
\hline States & st dev & 2.04 & 2.45 & 3.36 & 0.16 \\
\hline
\end{tabular}

Source: calculations on World Economic Outlook, International Monetary Fund. 


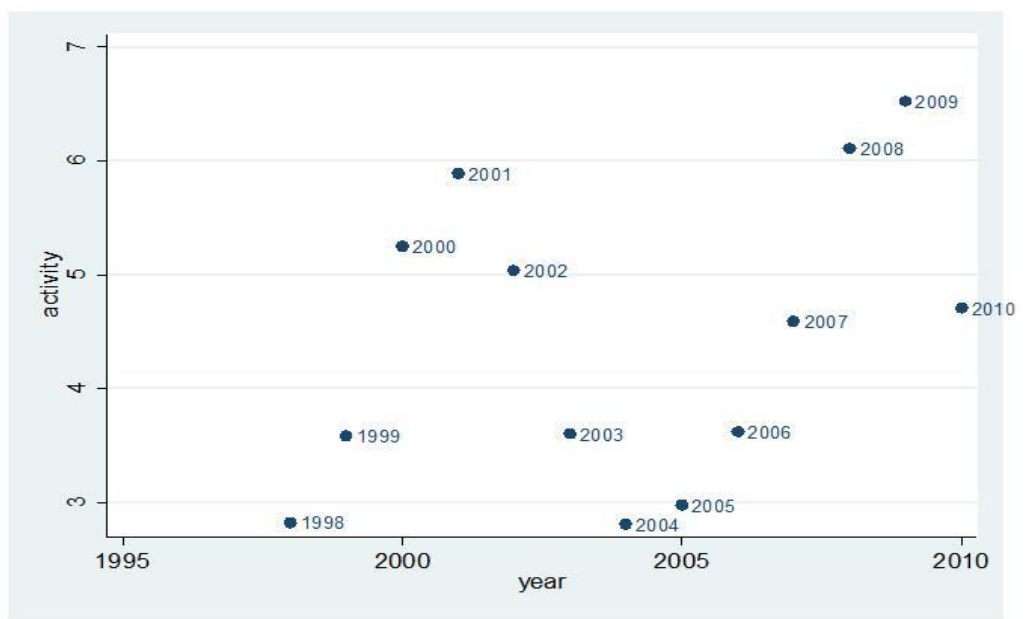

Figure B1. Market activity in the United States

Note: This graph provides a clear evidence of how financial crises affect some variables. For example, the variable architecture (but the same reasoning applies for other variables) which measures the financial system's activity level is driven by the two crises which occurred in the time period considered (dotcom bubble and Lehman's failure). Using this variable in a second stage regression in order to detect the effect of financial activity on technological change would have distorted the results due to exogenous shocks which have led the dependent variable we have chosen.

\section{(cc) $\mathrm{Br}$}

This work is licensed under a Creative Commons Attribution 3.0 License. 